Article

\title{
Risk-Based Approach for Informing Sustainable Infrastructure Resilience Enhancement and Potential Resilience Implication in Terms of Emergency Service Perspective
}

\author{
Pawel Gromek *(-) and Grzegorz Sobolewski \\ The Main School of Fire Service, Institute of Internal Security, Slowackiego 52/54 Street, 01629 Warsaw, Poland; \\ gsobolewski@sgsp.edu.pl \\ * Correspondence: pgromek@sgsp.edu.pl; Tel.: +48-602-582-66
}

Received: 2 April 2020; Accepted: 30 May 2020; Published: 2 June 2020

check for updates

\begin{abstract}
Infrastructure resilience ascribes into the United Nations' agenda for sustainable development. The more information supporting infrastructure resilience enhancement, the higher chance that it will be done objectively and effectively, and especially in a sustainable way. In spite of many different approaches and data sources, there is a lack of information that respects the emergency service point of view. The main research objective is to investigate factors determining sustainable infrastructure resilience enhancement that reflects direct protection of the most important values (human life and health) by connecting multiple variants of infrastructural resilience corresponding with the voice of emergency service and based on real data risk assessment. The methodology consists in formulation of a reference model for informing sustainable infrastructure resilience enhancement, risk assessment for infrastructure safety in terms of emergency service perspective and risk-based rationalization of the enhancement manners. The model stems from urban resilience and city resilience. Its components are physical resilience, structure and setting resilience, organizational resilience, economic resilience and legal resilience. These elements are related to hazards' character, operational specification and resource requirements, operationalizing the model in terms of emergency conditions. For risk rationalization purpose, 1,255,826 events which occurred in 2015-2019 are analysed. Nearly $70 \%$ of the summary value of infrastructural risk is related to residential buildings and other categories of objects (garages, auto repair shops, monuments of material culture, objects of natural environment, hydro-technical objects, military objects, ex-territorial objects and others). Sustainable-related manners are specified notably for abovementioned buildings and objects. Deepening the analysis of cognitive limitations gives ideas for further research.
\end{abstract}

Keywords: resilience; emergency; infrastructure; resilient infrastructure; risk; sustainability

\section{Introduction}

Sustainable development is a prime direction of the United Nations (UN) in the time framework of 2015-2030. Seventeen Sustainable Development Goals (SDGs) and 169 targets, which stem from the UN direction, reflect current issues transforming our world. UN Resolution 70/1 in 2015 [1] states that the development should be conducted in a sustainable way, to care for people in all forms of their existence, to protect the planet against natural and man-made hazards, to increase a common prosperity and to spread peace among nations and societies. A chance to achieve these objectives in the assumed time horizon strongly depends on partnership and cooperation between all world developers.

SDGs describe a holistic operational approach and concern all safety-related dimensions of the development. Consequently, they respect an entire spectrum of values which are important 
nowadays-values that are worth protecting nationally and internationally. Nevertheless, in the context of their unity, some of the values seem to be more important than others. This fact is highlighted when the most serious hazards occur. During floods (e.g., Italy 2019, Great Britain 2020), wildfires (Australia 2019, Spain 2019, etc.), hurricanes (e.g., Western Europe 2020) or pandemics (the whole world 2019-2020), human life and health (as well as property and environment in a scope of people's survival needs) gain in importance. Moreover, such events prove what is the most crucial for people existence in general, regardless of parentage, pigmentation, creed, ethnicity or beliefs.

Focusing on human life and health, building resilient infrastructure, promoting inclusive and sustainable industrialization and fostering innovation (SDG9), making cities and human settlements inclusive, safe, resilient and sustainable (SDG11) as well as taking urgent action to combat climate change and its impacts (SDG13) are worth addressing. The three interpenetrate each other and precisely concern sustainable infrastructure resilience enhancement, which is a core element of these goals' specification.

It is worth mentioning that current infrastructure resilience research concerns various resilience variants and presents points of view of disaster managers, ecologists, urban designers, local community representatives, etc. [2-4]. All of them can be implemented to increase infrastructure capability to rebound from threat circumstances, to absorb external shocks, to adapt to dynamic environmental changes and to modify organizational structure, operational mechanisms and external relations with infrastructure operators [2]. However, in most cases, they deal indirectly with the most important, utilitarian values and marginalize a voice of entities that protect the values in emergency conditions (direct danger to human life, time stress, etc.). It states a serious gap in infrastructure resilience theory (Gap 1).

Emergency service mindset for sustainable infrastructure resilience enhancement (SIRE) may shed light on a direct protection of human life and health. To express the sustainability character, a relevant approach should be based on established resilience concepts, respecting multiple resilience variants and adapting them to emergency service purposes. This can give additional, valuable research input to resilience science and sustainability science, especially in relation to UN Sustainability Development Goals [5]. Such proceeding will be an example of a holistic manner, with a high potential to identify extraordinary facts about SIRE [6,7]. Furthermore, it will face the next gap (Gap 2)—focusing mostly on selected resilience issues in emergency discussion [2,8-11], when a comprehensive analysis is characterized by a great potential to obtain new ideas for infrastructure resilience enhancement $[12,13]$.

Current emergency perspectives of SIRE boil down to life-safety and collapse prevention, where the primary objective is to design the minimum level of threat (risk) to be tolerated. This has its expression in building codes and other formal regulations $[14,15]$. From a practical point of view, it is advisable to ensure that the emergency service approach for SIRE is operationalized on the basis of real data (real level of risk which is not tolerated every time), in an exact connection with the most serious kinds of events (hazards) affecting the most important utilitarian values. This is relatively hard to achieve using only codes and formal regulations. So, the third gap (Gap 3) of the research can be noticed-a lack of bottom-up manners using real emergency data which present not minimal acceptable but real level of risk to rationalize SIRE manners. As far as this point is concerned, a risk-based approach (especially quantitively-specified) $[16,17]$ with a rationalization module is desirable. Operationalizing emergency service data can be significantly useful to prioritize the SIRE manners in terms of risk assessment results [18].

Preconcluding, the main research objective is to investigate factors determining sustainable infrastructure resilience enhancement in emergency service mindset. The specific objectives may be outlined as follows:

1. To elaborate a reference model for SIRE which deals directly with the most important, utilitarian values and considers mindset of entities that protect the values in emergency conditions (direct danger to human life, time stress, etc.);

2. To assess infrastructure risks respecting emergency conditions in a holistic way; 
3. To formulate the risk-rationalized manners for SIRE using real data related to emergency interventions.

This paper proposes an approach which stems from multiple resilience concept, morphological analysis and quantitative risk assessment method. The sustainability orientation allows us to evaluate the resilience concepts with the emergency-related one. The morphological approach gives foundations for identification of the riskiest categories of infrastructural objects. The risk assessment concretizes the identification by the use of real data. For this purpose, data collected by the State Fire Service (SFS) entities in 2015-2019 is implemented. Analysis of 1,255,826 events serves to rationalize SIRE manners. The paper takes into account the emergency service point of view that is relatively rare in infrastructure sustainability and resilience research. The point of view is expressed by direct use of the emergency service data base. Relevant classes of consequences correspond with crucial emergency operational measures (e.g., hazard zone dimension, extinguishing intensity, number of victims, required resources). Furthermore, three core emergency service operational issues determine SIRE manners. There are hazard attributes (common exposure to population, a wide spectrum of classes of consequences and cascading potential for development), operational specification (urgency, continuity and substitutability of tasks, operations and activities) and resource requirements (adequacy, limitation and substitutability of resources). Authors verified the manners also with respect to their operational experiences related to emergency services.

Due to its practicality, the research delivers an output useful for decision-makers responsible for BRI SIRE. It operationalizes SDG9 (in terms of development of sustainable and resilient infrastructure to support human well-being for all), SDG11 (regarding creating conditions for making housing, public services, cultural and natural heritage safe and effectively protected against hazards) and SDG13 (strengthening resilience and adaptive capacity to climate-related hazards and natural disasters in all countries). As buildings and infrastructure must withstand extreme events to be named resilient [19], this study gives practical information on how to do this in a sustainable way.

\section{Theoretical Background}

\subsection{Sustainability and Resilience of Infrastructure—General Premises}

Bibri and Krogstie state that sustainability is a difficult concept which relates to multiple areas of socioecological system operation [20]. Synthetically, sustainability means the ability to maintain entity (system) at a certain (desired, optimal, rational, etc.) level of operation. In general, sustainability concerns chronic types of threats [21]. The long-term specification of sustainability goals is expressed by the focus on social, environmental and economic issues in terms of increasing quality of life for the present and the future generations [22].

The infrastructure context of the research allows us to reduce the general perception into urban sustainability and sustainable city phenomenon, especially when the sustainability approach is a perspective way for cities to better cope with existing and future conditions [23]. Consequently, infrastructure sustainability is an ability of the infrastructural dimension of the city (urban area) to improve the quality of inhabitants' life as well as efficiency of urban services and operation. Simultaneously, it respects economic, social, environmental and cultural needs for current and future generations [24]. A city which fits this definition can be named a sustainable city.

Focusing on resilience, it broadly means the capacity for quick recovery from widely perceived difficulties and obstacles. Typically, it concerns acute types of threats and treats about broad response due to the entity (system) operation [21].

Different ideas for resilience shed light on multiple dimensions of this issue. It can be perceived widely, in the context of vulnerability [25], adaptation to hazards [26], general characteristics (robustness, stability, redundancy, diversity, flexibility, modularity, self-organization, efficiency, etc.) and management stages (planning/preparation, absorption, recovery and adaptation) [27] and is implemented in many cities around the world [28,29]. More selectively, Bec, Moyle and Moyle connect 
it with economic and psychological factors [30]. McEvoy states that climate resilience should be dealt with as an element of urban development. An influence also on the infrastructure sphere may be noticed [31,32]. This is especially important for critical infrastructure protection [33,34].

Many directions for scientific exploration of resilience can cause confusion about its essence when infrastructure resilience is described. To overcome this cognitive obstacle, as infrastructure is an integral component of the city, there should be a strong correspondence between city resilience and infrastructure resilience definitions. Especially, when "infrastructure systems are widely acknowledged to be a lifeline in the community and play a pivotal role in sustaining ( . . . ) urban resilience and sustainability" [35]. Therefore, city resilience " $(. .$.$) is defined as the capacity of individuals, communities, institutions,$ businesses, and systems within the city to survive, adapt, and grow no matter what kinds of $(\ldots)$ stresses and (... ) shocks they experience" [36]. In conclusion, infrastructure resilience definition expresses the capacity to withstand in case of, desirably, a whole spectrum of stresses and shocks (e.g., hurricane, fire, explosion). This utopian assumption is rationalized by Linkov at al., who boil down the meaning to increase the withstanding capacity in accordance to at least some of the consequences of the threat occurrence, to ensure continuity of the most important functions, to minimize the reconstruction time and to ensure that infrastructure will be more resilient for such kind of threat in the future [37]. These can be done by increasing " $(\ldots$ ) the ability to prepare and plan for, absorb, recover from and more successfully adapt to adverse events". [38].

It is worth emphasizing misunderstandings which concern sustainability and resilience. Marchese at al. [39] present three important concepts, which describe their mutual relations. Firstly, resilience is dealt with as a component of sustainability. From the operational point, when the system resilience increases, the system is more suitable. However, this relation does not need to be bilateral in all cases. Secondly, sustainability is a component of resilience. In this meaning, when the system sustainability increases, the system is more resilient. Analogically to the previous approach, the relation does not need to be bilateral as well. Thirdly, sustainability and resilience are separate objectives.

Each abovementioned concept has relevant proponents and opponents, related to the area of application [39]. This highlights a complexity of analysed issues and shows potential chances for SIRE to meet global sustainability goals. Although from the emergency perspective the resilience seems to be more important than sustainability (at the highest level of generality), one concept can be implemented to the other, and vice versa. So, synergy effect might be generated [40] and used for SIRE in terms of emergency conditions (filling Gap 1).

\subsection{Building Resilient Infrastructure in a Sustainable Way}

Based on general premises of sustainability and resilience of infrastructure, we can conclude that relations between sustainability and resilience are bidirectional—sustainability can influence the system resilience and resilience may determine the system sustainability. Many ideas prove this in theory and practice. In accordance with the UN development framework [1], the infrastructure resilience is connected with sustainable urban operation [41,42], and more precisely, with sustainability in the light of extreme events (e.g., natural hazards) [43]. Moreover, Kloosterman, Veeneman and van der Hoek conclude that sustainable societal infrastructure influences conflicting claims of infrastructures [44], which proves a strong connection between resilience and sustainability in the analysed context. Infrastructure is an element of local society and is connected with other elements (resources, processes, people, institutions, activities) [35,45] Thus, a sustainable way of thinking about infrastructure resilience enhancement relates to multiple groups of environmental, social and economic indicators [46]. The prime challenge is to connect sustainability and resilience into one concept which will be useful for SIRE purposes in the light of the emergency mindset. Sustainability holistic specification seems to face Gap 2 and to state a preliminary intention of the sustainability-resilience connection. This is why, in the described context, the connection can be dual. Firstly, direct and indirect associations with SDG9, SDG 11 and SDG13 are noticed. Secondly, sustainability can constitute a 
comprehensive framework for SIRE, order multiple resilience variants and create a coherent notion of SIRE.

At this stage, one can expect a lack of tools and methods to evaluate and improve such an infrastructure resilience concept [38]. Following Gap 3, the bottom-up manner using real emergency data which present not minimal acceptable but real level of risk is desired. Its elaboration will allow to create foundations for risk assessment which is very typical for building (infrastructure) resilience analysis $[14,47,48]$. Furthermore, the risk-based approach can rationalize manners for SIRE. Even if its holistic specification can give unique possibilities for identification of extraordinary findings, focusing on many unimportant determinants and other kinds of elements in one analysis requires often much workload (especially when a strong variant of morphological analysis is taken into account) $[49,50]$. When the riskiest areas of research are considered, there will be a great chance to aim only at the most important SIRE issues.

Moreover, "it can be difficult to validate or generalize what effective resilience means in practice" [51]. Thus, successful exploration of resilience by various risk management activities proves the risk usefulness in terms of resilience analysis and measurement. When "globally or nationally accepted thresholds to characterize high or low resilience do not exist" [52], risk can indirectly express this issue.

\section{Materials and Methods}

\subsection{General Cognitive Model}

Specific research objectives play a reference role in a general cognitive model composition. Figure 1 presents the model elements and relations between them.

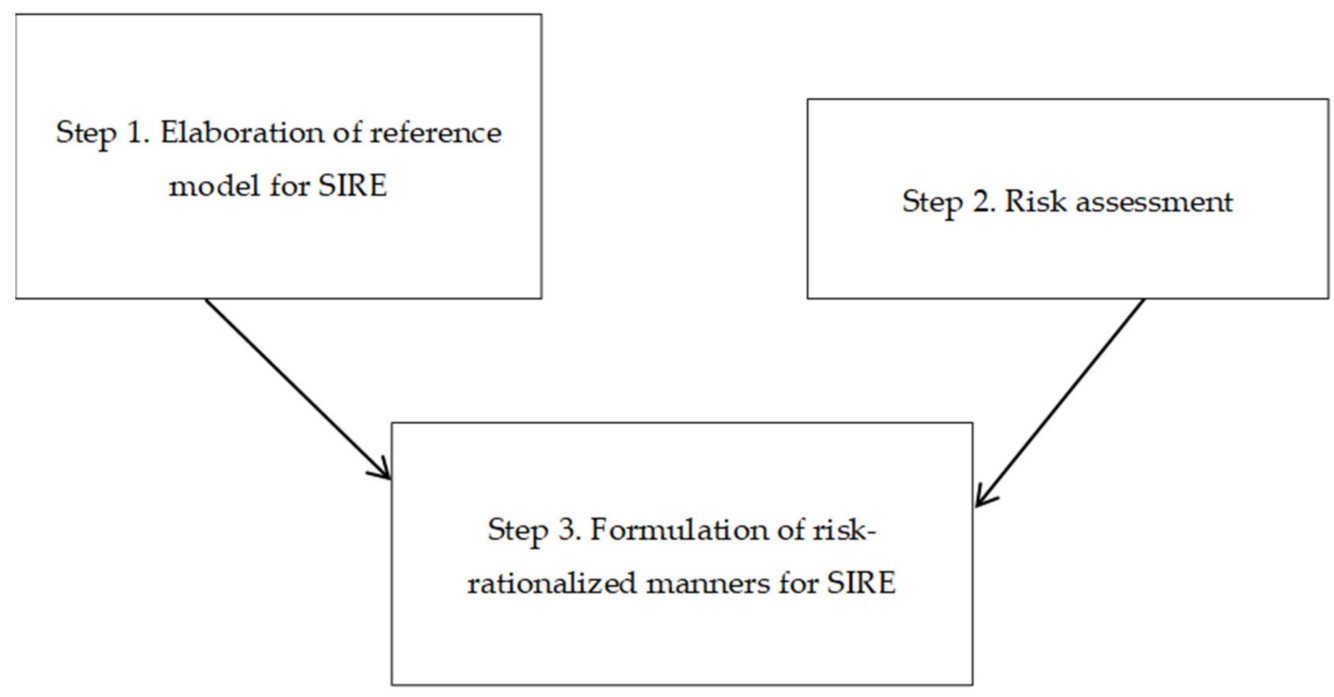

Figure 1. General cognitive model of the research.

The general cognitive model of the research orders particular steps of the research methodology. It serves as a simplified structure of relevant activities which are planned to achieve specific research objectives. Each step is dedicated to a relevant specific objective and can be developed as follows.

Step 1. Elaboration of SIRE model

From the viewpoints of science and practice, a process of SIRE needs to be recurrent. Thus, the reference model for infrastructure resilience is desired. Due to UN Resolution 70/1 as well as sustainability and resilience essence, the model should:

1. Correspond with UN directions of the world development and relevant challenges; 
2. Refer to systemic character of the infrastructure which is an element (subsystem) of the entire community (system of subsystems);

3. Refer to sustainability essence;

4. Be concrete (possible to be measured, giving additional information for risk assessment purposes).

The model formulation will be helpful in SIRE manners' design. Then, all of the model elements should be taken into consideration from the holistic point of view.

Step 2. Risk assessment

The second step requires collection of information that allows for the creation of a situational picture on infrastructure safety. The more detailed the information, the more effective is the process of the risk assessment. So, the information should meet the following requirements:

1. To be based on real data;

2. To concern kinds of events affecting the most important, utilitarian values;

3. To be confirmed by legal safety authorities (institutions);

4. To be actual (approximately 5 years);

5. To be implementable to a general risk assessment method.

The last requirement presents a prime reason for the information collection. As safety is an intangible phenomenon, risk can play the role of safety measure [16,17]. This justifies an implementation of risk assessment into a collection of information concerning infrastructure resilience (resilience understood as an aspect of safety). So, a risk assessment method (adequate for the research assumptions) should be used.

Step 3. Formulation of risk-rationalized manners for SIRE

The manners for SIRE should stem from infrastructure categories which are taken into account in the risk assessment. A correspondence to the SIRE model is also required. So, in terms of methodological effectiveness, formulation of the manners should be done in a holistic way, considering all the categories, in light of all elements of the model.

Such use of holistic approach can result in a relatively complex catalogue of the manners. This is why an evaluation technique is simultaneously needed to rationalize the manners and make their catalogue more implementable to the practice. In a reference to previous requirements, the technique should allow for the rationalizations of the manners regarding the risk assessment results.

\subsection{Operationalization of the Model Elements}

\subsubsection{Elaboration of Reference Model for SIRE}

Theoreticians and practitioners have been looking for a universal resilience model for many years [53,54]. So far, several solutions that can be used for SIRE analysis have been developed. Following other researchers who carried out a widely designed literature exploration, the resilience building should consider stakeholders' involvement regarding such aspects as collaboration and networking, awareness and commitment, learning as well as training and preparedness [36], giving reference to the resilience maturity model [55]. This catalogue can be developed by "community-based risk assessments, disaster and risk reduction; integrated urban planning, development and logistics; integrating solutions into all aspects of city management (system solutions); addressing most vulnerable groups; financing, including the private sector; cooperation and implementing process on the ground; decision supporting tools, legislation and flexible implementation networks; political will; integration of environmental aspects: green urban economy, urban agriculture, green infrastructure, renewable energy" [55,56]. This is the same as the Rockefeller Foundation framework, which describes the resilience concept using 4 categories, 12 indicators, $48-54$ subindicators and $130-150$ variables [57]. As the infrastructure resilience is an integral part of the community resilience, the first is determined by factors ascribed into such areas of operation as science and technology, community organization and institutes, the natural environment and social-economic status [58], environmental component, public service and 
management system [59]. The factors can also be related to the urban resilience principles: response and adaptive capacity, participation and inclusiveness, spatial planning, social equity and learning [60] and in the next approach to urban structure and setting resilience, physical resilience, sociohuman resilience, economic resilience as well as managerial, institutional and legal resilience [19]. In addition, they match the critical infrastructure elements resilience assessment areas (CIERA model areas: technical resilience and organizational resilience) [48]. A cognitively interesting mindset relates to a quantitative method for assessing resilience of interdependent infrastructures. It connects the infrastructure resilience with absorptive, adaptive and restorative capabilities, highlighting rather general directions for SIRE manners design than concrete resilience variants, kinds or areas [6]. The system resilience analysis can be carried out with the respect of logical and physical resilience, personal resilience, organizational resilience and cooperative resilience as well [7].

Many ideas for the infrastructure resilience concept indicate different approaches, that fragmentarily or fully meet each other. Their coherence stems from the same object of analysis and all of them include infrastructure component (directly or indirectly). Nevertheless, particular propositions are based on relevant foundations and marginally match the emergency view on SIRE. Given that infrastructure resilience enhancement manners need to be designed in a sustainable way, it is required to connect chosen resilience areas of analysis (variants, indicators, etc.) into one reference model for SIRE. As far as Gap 1 and Gap 2 are concerned, the urban resilience concept [19] can be a starting point to achieve this goal after emergency and sustainability concretization. Its critical implementation into the research framework allows to formulate the model, as it is presented in Figure 2.

1. Physical resilience: in general, particular infrastructure elements (buildings, systems, subsystems, installations, etc.) need to be resistant to all kinds of hazards, the current ones and provided ones. As a full spectrum of natural disasters and man-made hazards is concerned, the infrastructure physical characteristics should be adequate for the hazards' specification and development mechanisms. From a practical point of view, this should ensure at least the lowest accessible level of quality for infrastructure functionalities that are most important currently and are said to be significant in the future [61,62].

2. Structure and setting resilience: infrastructure (and its particular elements) cannot be considered separately from other infrastructures and their elements. Relevant interconnections show that they are interdependent and, mainly, the infrastructure (or a system of infrastructures) is as resilient as its weakest element. This is why considering the interconnections is vital for effectiveness of the resilience building process to ensure a proper level of human life quality [63], just like the cascading effect of hazards occurrence [64].

3. Organizational resilience: infrastructure is mostly operated by people and they commonly constitute an organization (of work, institutions, etc.). So, sufficient organizational resilience is crucial to keeping the highly desirable synergy effect between infrastructure and staff in the organization, without regard for operational circumstances (in terms of hazards and operational threats that occur currently and could occur in the future) [65]. Following Rehak, this purpose can be met by focusing on risk management, organizational innovation processes and educational and development processes [66].

4. Economic resilience: Every sustainability- and resilience-centred operation needs resources which are finally convertible into financial capabilities of the infrastructure operator, owner and/or supervisor. It has a primary role in pre- and postevent activities, significantly determining real capabilities for prevention as well as infrastructure reconstruction and recovery [19].

5. Legal resilience: formal framework for SIRE is put to the test especially when some unexpected event occurs. When inadequacy to actual situational conditions is noticed, legal acts are generally changed. As it often takes some time and is loaded with merit and technical defects, legal resilience measured by flexibility and generality is required. It is crucial in the context of chronic types of threats that affect social, environmental and economic issues of human existence and operation. 


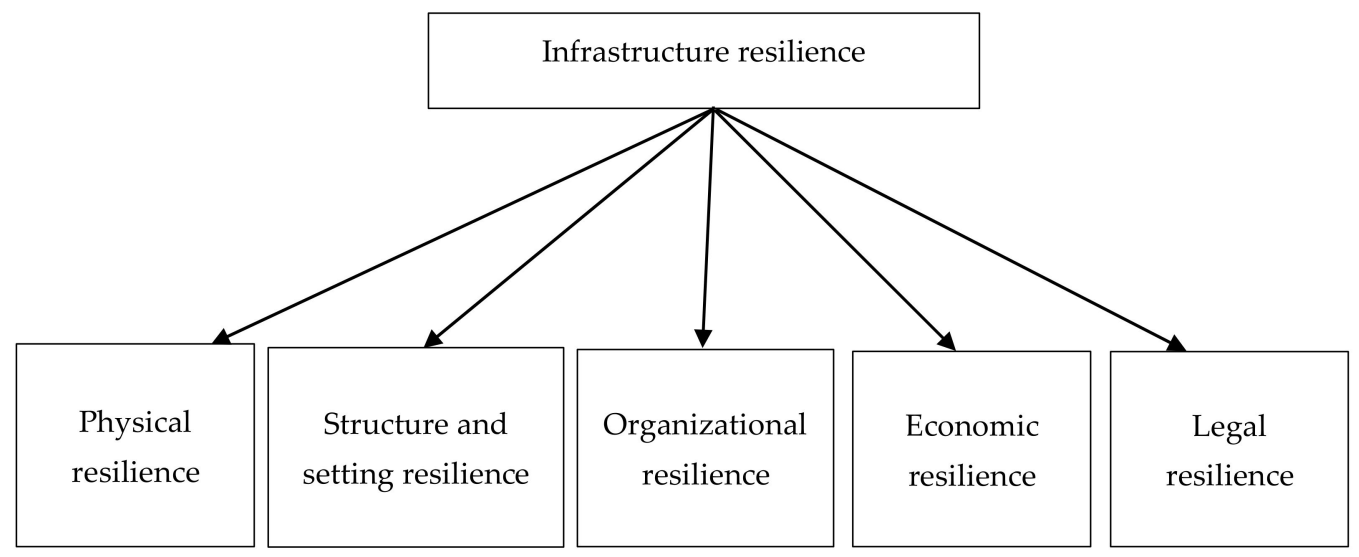

Figure 2. Reference model for sustainable infrastructure resilience enhancement (SIRE) (RM-SIRE).

The model gives general directions to formulate infrastructure resilience enhancement manners in a sustainable way. Considering its composition, significant variants of resilience are connected, facing Gap 2. Moreover, the model is related to community resilience (as a superior system where infrastructure is a relevant subsystem) matching to all stages of disrupting event (prepare, absorb, recover, adapt) and major subcomponents of any system (physical, information, cognitive and social) [67]. In addition, it presents a multidimensional view into sustainable connection of multiple variants of resilience (physical, structure and setting, organizational, economic, legal), strongly ascribing to SDG9, SDG11 and SDG13 [1]. Owning to its universality, its potential is expressed by a possibility of implementation in many different cognitive (theoretical and practical) mindsets for SIRE. The perspective of emergency service can be one of them (Gap 1). However, the model concretization needs to meet characteristic aspects of the chosen perspective, preferably in a holistic way (e.g., a morphological approach).

\subsubsection{Risk Assessment}

Resilience generates learning processes to improve the system capacity for dealing with hazards and the processes are supported, among others, by raising risk awareness [68]. For this reason, risk assessment can be understood as a way to find out a general view on the resilience needs, also in the context of emergency service and notably when resilience and risk have been commonly taken into consideration $[69,70]$.

Considering Gap 1 and Gap 3, it is not so critical to have information about the resilience level as the risk level. Theoretically, very resilient infrastructure objects can be seriously affected by hazards and need still additional effort to increase their resilience. So, generally, high resilience level does not inherently imply low risk level. Risk awareness influences knowledge about directions to increase the resilience and this is crucial from emergency service which operates, controls, investigates and regulates infrastructure conditions. Consequently, risk assessment can be used for SIRE rationalization.

Lack of bottom-up manners using real emergency data to rationalize SIRE manners (Gap 3) justifies searching for data and information collected directly by emergency service. That is why the data base from SFS is implemented [71], especially when real data-based solutions give generally the most exact foundations for the risk assessment [72].

SFS is a prime, executory societal security institution in Poland. Because it organizes the state firefighting rescue system (SFRS) [73], it is said as the crucial emergency entity in the state. Usefulness of the data base is emphasized by the fact that SFS is the main institution directly dedicated to active infrastructure protection against societal security hazards (natural disasters and man-made hazards). Regarding this, it describes all events when serious hazard occurs and human life, health, property and environment are in danger. This states the base to be a reference in the analysed context, notably when data collection process is structured, formalized and obligated by the law [74]. 
The data base is comprised of two categories of events. The first category contains fires (F), which are understood as uncontrolled combustion processes in undesirable places. The second category mentions local hazards (LH), which means any kind of negative phenomenon apart from fires and state danger to people, property or environment, resulting from civilization development, people operations or natural disasters [74].

Table 1 collects information about particular classes of consequences ascribed to particular categories of events.

Table 1. Classes of consequences in State Fire Service (SFS) data base.

\begin{tabular}{|c|c|c|}
\hline $\begin{array}{l}\text { Consequence } \\
\text { Measure (C) }\end{array}$ & Class of Consequence & Categorization Premises \\
\hline 1 & Small F (S/F) & $\begin{array}{l}\text { burning area of } 70 \mathrm{~m}^{2} \text { or } \\
\text { volume of } 350 \mathrm{~m}^{3} \text { or } \\
\text { forests, fields, peat bogs and wasteland at area lower than } 1 \text { ha } \\
\text { events which require maximum } 4 \text { extinguishing jets }\end{array}$ \\
\hline 2 & Medium F (F/M) & $\begin{array}{l}\text { burning area from } 71 \mathrm{~m}^{2} \text { to } 300 \mathrm{~m}^{2} \text { or } \\
\text { volume of } 351 \mathrm{~m}^{3} \text { to } 1500 \mathrm{~m}^{3} \text { or } \\
\text { forests, fields, peat bogs and wasteland at area from } 1 \text { ha to } 10 \text { ha or } \\
\text { events which require from } 5 \text { to } 12 \text { extinguishing jets }\end{array}$ \\
\hline 3 & $\operatorname{Big} F(F / B)$ & $\begin{array}{l}\text { burning area from } 301 \mathrm{~m}^{2} \text { to } 1000 \mathrm{~m}^{2} \text { or } \\
\text { volume of } 1501 \mathrm{~m}^{3} \text { to } 5000 \mathrm{~m}^{3} \text { or } \\
\text { forests, fields, peat bogs and wasteland at area from } 10 \text { ha to } 100 \text { ha or } \\
\text { events which require from } 13 \text { to } 36 \text { extinguishing jets }\end{array}$ \\
\hline 4 & Very big F (F/VB) & parameters that exceed values for $\mathrm{F} / \mathrm{B}$ \\
\hline 1 & Small LH (LH/S) & $\begin{array}{l}\text { scope-limited events, conducting without the use of specialized equipment } \\
\text { (excepting measurement instruments which identify no agents) }\end{array}$ \\
\hline 2 & $\begin{array}{l}\text { Locally-limited LH } \\
\qquad(\mathrm{LH} / \mathrm{L})\end{array}$ & $\begin{array}{l}\text { urgent failures of machines, instruments, vehicles and another object, when: } \\
\text { maximum } 1 \text { victim is dead or } \\
\text { maximum } 3 \text { victims are supported by medical rescue teams (from outside } \\
\text { SFRS) or } \\
\text { maximum } 4 \text { fire service teams (12-24 rescuers) participate in the action }\end{array}$ \\
\hline 3 & Medium LH (LH/M) & $\begin{array}{l}\text { urgent failures of machines, instruments, vehicles and another object, when: } \\
2-3 \text { victims are dead or } \\
4-10 \text { victims are supported by medical rescue teams (from outside SFRS) or } \\
\text { maximum 5-12 fire service teams (15-72 rescuers) participate in the } \\
\text { action or } \\
1 \text { special rescue unit supports the primary rescue resources }\end{array}$ \\
\hline 4 & Big LH (LH/B) & $\begin{array}{l}\text { urgent, unforeseen event, which refers to mass danger to human life, health, } \\
\text { property or environment, exceeds quantitative values of } \mathrm{LH} / \mathrm{M} \text { and requires } \\
\text { SFRS resources in strength of } 1 \text { battalion (to } 480 \text { rescuers) }\end{array}$ \\
\hline 5 & $\begin{array}{l}\text { Catastrophic LH } \\
\quad(\mathrm{LH} / \mathrm{C})\end{array}$ & $\begin{array}{l}\text { urgent, unforeseen event, which refers to mass danger to human life, health, } \\
\text { property or environment and requires SFRS resources in strength of at least } \\
\text { of } 1 \text { battalion (at least } 480 \text { rescuers) }\end{array}$ \\
\hline
\end{tabular}

Source: own elaboration based on [74].

Particular classes of consequences reflect emergency service information needs (e.g., size of the hazard zone, required resources, number of victims) and are described in SFS operational guidelines [75]. The class of consequence of the event is elaborated by the officer in charge of the emergency action directly during the action with the use of the guidelines. Then, information about the event class of consequence is reported to the SFS data base by the officer.

Division of all negatively-perceived events into particular consequence classes opens an opportunity to implement the data into general risk assessment method, when risk is " $(\ldots)$ a derivative of accidents frequency and relevant results (consequences)" [75] and corresponds with other 
risk assessment methods dedicated to infrastructure safety [76]. The data base gives both required factors and the risk can be assessed with the use of the following equation:

$$
R Y_{(F / L H) i, j}=P Y_{(F / L H) i, j} \times C_{i}
$$

where: $R Y_{(F / L H) i, j}: \mathrm{F} / \mathrm{LH}$ risk index for $i$-class of consequences and $j$-category of infrastructural objects in $Y$-year; $P Y_{(F / L H) i, j}$ : frequency of events for $i$-class of consequences and $j$-category of infrastructural objects in $Y$-year; $C_{i}$ : consequence measure which corresponds to $i$-class of consequences.

Infrastructure can be divided into particular categories of infrastructural objects (j-category of infrastructural objects), indicating more precise information about emergencies in the analysed period of time. SFS data base gives such kind of division, which is displayed in Table 2.

Table 2. Categories of infrastructure objects.

\begin{tabular}{|c|c|c|}
\hline Code & $\begin{array}{c}\text { Name of the } \\
\text { Category }\end{array}$ & Kinds of Infrastructural Objects in the Category \\
\hline $\mathrm{O} 1$ & $\begin{array}{l}\text { Public utility } \\
\text { buildings }\end{array}$ & $\begin{array}{l}\text { Office administration facilities, banks } \\
\text { Research and education facilities (incl. didactics buildings, schools, } \\
\text { kindergartens) } \\
\text { Health service facilities (incl. hospitals, sanatoriums, social care homes, } \\
\text { clinics, childcare facilities) } \\
\text { Commercial-service facilities (incl. shops, department stores, gastronomical } \\
\text { places, wholesale warehouses) } \\
\text { Passenger service facilities (incl. railway stations, bus stations, river and } \\
\text { marine ports) } \\
\text { Spectacle, entertainment and sport facilities } \\
\text { Religious and sacral facilities } \\
\text { Museums, antique building museums, exhibitions, galleries } \\
\text { Libraries, archives } \\
\text { Penitentiary facilities } \\
\text { Other Public utility buildings }\end{array}$ \\
\hline $\mathrm{O} 2$ & Residential objects & $\begin{array}{l}\text { Hotels and flophouses } \\
\text { Orphanages } \\
\text { Dormitories, student residence halls } \\
\text { Barracks } \\
\text { Retirement homesHoliday houses, guesthouses } \\
\text { Shelters } \\
\text { Single-family houses (incl. semi-detached houses and terraced houses) } \\
\text { Farms } \\
\text { Others }\end{array}$ \\
\hline $\mathrm{O} 3$ & Production objects & $\begin{array}{l}\text { Factories } \\
\text { Outbuildings } \\
\text { Social objects } \\
\text { Technological installations outside the buildings } \\
\text { Technological machines and devices } \\
\text { Administration facilities } \\
\text { Pipelines }\end{array}$ \\
\hline $\mathrm{O} 4$ & Warehouse objects & $\begin{array}{l}\text { Warehouses and shelters in production areas } \\
\text { Warehouses and shelters (excepted O1 and these in production areas) } \\
\text { Warehouses and shelters in areas dedicated to people presence } \\
\text { Building sites and building backrooms } \\
\text { Storage squares } \\
\text { Containers and tanks } \\
\text { Fuel stations and gas stations } \\
\text { Fuel bases and gas bases }\end{array}$ \\
\hline
\end{tabular}


Table 2. Cont.

\begin{tabular}{|c|c|c|}
\hline Code & $\begin{array}{l}\text { Name of the } \\
\text { Category }\end{array}$ & Kinds of Infrastructural Objects in the Category \\
\hline O5 & $\begin{array}{l}\text { Agricultural } \\
\text { buildings }\end{array}$ & $\begin{array}{l}\text { Buildings and installations for processing of agricultural produce } \\
\text { Livestock, breeding and warehouse buildings, greenhouses } \\
\text { Farm buildings }\end{array}$ \\
\hline O6 & Others & $\begin{array}{l}\text { Garages } \\
\text { Auto repair shops } \\
\text { Monuments of material culture (not buildings) } \\
\text { Objects or set of objects of natural environment } \\
\text { Hydrotechnical objects } \\
\text { Military objects } \\
\text { Exterritorial objects (incl. Consulates, embassies) } \\
\text { Others }\end{array}$ \\
\hline
\end{tabular}

Source: own elaboration based on [74].

Table 3 presents numbers of events that occurred in 2019 as a statement from the SFS data base. It proves the base potential in the light of risk assessment, as an exact relation between event frequency $\left(P Y_{(F / L H) i, j}\right)$ and their consequences $\left(C_{i}\right)$ is noticed.

Table 3. Numbers of events in 2019.

\begin{tabular}{cccccccc}
\hline \multirow{2}{*}{$C_{\boldsymbol{i}}$} & Class of Consequence $(\boldsymbol{i})$ & \multicolumn{6}{c}{ Category of Infrastructural Objects $(\boldsymbol{j}){ }^{*}$} \\
\cline { 3 - 8 } & & $\mathbf{O 1}$ & $\mathbf{O 2}$ & $\mathbf{O 3}$ & $\mathbf{O 4}$ & O5 & O6 \\
\hline 1 & $\mathrm{~F} / \mathrm{S}$ & 2240 & 30,997 & 2023 & 827 & 1947 & 12,847 \\
2 & $\mathrm{~F} / \mathrm{M}$ & 73 & 964 & 310 & 174 & 704 & 400 \\
3 & $\mathrm{~F} / \mathrm{B}$ & 12 & 32 & 56 & 40 & 100 & 26 \\
4 & F/VB & 5 & 1 & 26 & 12 & 24 & 3 \\
& Totally: & 2330 & 31,994 & 2415 & 1053 & 2775 & 13,276 \\
\hline 1 & LH/S & 6601 & 20,670 & 462 & 265 & 273 & 7800 \\
2 & LH/L & 10,839 & 75,288 & 2724 & 713 & 3631 & 66,676 \\
3 & LH/M & 301 & 936 & 185 & 159 & 31 & 461 \\
4 & LH/B & 6 & 15 & 3 & 1 & 1 & 26 \\
5 & LH/C & 0 & 0 & 0 & 0 & 0 & 0 \\
& Totally: & 17,747 & 96,909 & 3374 & 1138 & 3936 & 74,963 \\
\hline
\end{tabular}

* the objects are codded in Appendix A.; Source: own elaboration based on [71].

Use of Equation (1) allows us to recalculate values in Table 3 into risk indexes for particular categories of infrastructural objects in the analysed year. Table 4 shows results of direct multiplication of $P 2019_{(F / L H) i, j}$ and $C_{i}$.

To meet the research objectives and increase the awareness about infrastructural safety during the last five years, additional calculations to estimate yearly-average risk index is required. Equation (2) presents relevant relations, as follows:

$$
\overline{\operatorname{RTH}}_{(F / L H) i, j}=\overline{P Y}_{(F / L H) i, j} C_{i}
$$

where: $\overline{R T H}_{(F / L H) i, j}$ : yearly-average $\mathrm{F} / \mathrm{LH}$-risk index for $i$-class of consequences and $j$-category of infrastructural objects in analysed time horizon $(T H) ; \overline{P Y}_{(F / L H) i, j}:$ yearly-average frequency of events for $i$-class of consequences and $j$-category of infrastructural objects in analysed time horizon $(\mathrm{TH}) ; C_{i}$ : consequence measure which corresponds to $i$-class of consequences.

Moreover, appointment of distribution for summary yearly risk indexes for $\mathrm{F} / \mathrm{LH}$ allow us to analyse relevant trends and conclude whether some changes are highly expected during the next 
years. The following equation presents a computational apparatus to do this using data from the SFS data base.

$$
R S Y_{(F / L H) i, j}=\sum_{i} R Y_{(F / L H) i, j}
$$

where: $R S Y_{(F / L H) i, j}:$ summary yearly $\mathrm{F} / \mathrm{LH}$ risk index for $i$-class of consequences and $j$-category of infrastructural object in $Y$-year.

Equation (2) gives summary values of risk for all events in the calculated year. From this point, comparison of infrastructure risk (and safety as well) levels in these particular years is possible.

Table 4. Risk indexes for particular categories of infrastructural objects in $2019\left(R 2019_{(F / L H) i, j}\right)$.

\begin{tabular}{|c|c|c|c|c|c|c|c|}
\hline \multirow{2}{*}{$C_{i}$} & \multirow{2}{*}{ Class of Consequence (i) } & \multicolumn{6}{|c|}{ Category of Infrastructural Objects $(j)$} \\
\hline & & 01 & $\mathrm{O} 2$ & $\mathrm{O} 3$ & $\mathrm{O} 4$ & O5 & O6 \\
\hline 1 & $\mathrm{~F} / \mathrm{S}$ & 2240 & 30,997 & 2023 & 827 & 1947 & 12,847 \\
\hline 2 & $\mathrm{~F} / \mathrm{M}$ & 146 & 1928 & 620 & 348 & 1408 & 800 \\
\hline 3 & $\mathrm{~F} / \mathrm{B}$ & 36 & 96 & 168 & 120 & 300 & 78 \\
\hline \multirow[t]{2}{*}{4} & F/VB & 20 & 4 & 104 & 48 & 96 & 12 \\
\hline & Totally: & 2442 & 33,025 & 2915 & 1343 & 3751 & 13,737 \\
\hline 1 & $\mathrm{LH} / \mathrm{S}$ & 6601 & 20,670 & 462 & 265 & 273 & 7800 \\
\hline 2 & LH/L & 21,678 & 150,576 & 5448 & 1426 & 7262 & 133,352 \\
\hline 3 & $\mathrm{LH} / \mathrm{M}$ & 903 & 2808 & 555 & 477 & 93 & 1383 \\
\hline 4 & LH/B & 24 & 60 & 12 & 4 & 4 & 104 \\
\hline \multirow[t]{2}{*}{5} & LH/C & 0 & 0 & 0 & 0 & 0 & 0 \\
\hline & Totally: & 29,206 & 174,114 & 6477 & 2172 & 7632 & 142,639 \\
\hline
\end{tabular}

\subsubsection{Formulation of Risk-Rationalized Manners for SIRE}

The last step is conducted to create a catalogue of manners for SIRE. Pursuing the holistic result of the enhancement process, the morphological approach is highly recommended, especially when it is successfully implemented into sustainability and disaster risk reduction issues $[77,78]$.

To achieve the research objectives, the morphological analysis must concern:

1. All categories of objects (6 categories).

2. All classes of consequences (9 classes).

Logical multiplication of 6 categories and 9 classes gives a total number of 45 potential analysis connections. Moreover, it maximizes chances to identify all realistic and rationally-determined manners. Nevertheless, the total number can be too high to formulate practical guidelines, especially for decision makers who expect short and concrete tips. Considering the risk assessment results can limit the total output from the morphology analysis only to the connections justified by the infrastructural risk values and specification. The connections prioritization is possible, because use of Equation (2) indicates objects which are more in danger than others. Thus, the objects can be risk-ordered and consequently prioritized (1st priority for the most risky objects, 2nd priority to the less risky objects, etc.).

Figure 3 presents a simplified view into the prioritization result.

The abovementioned figure presents a result of prioritization for connections "category of object-class of consequence" sorted on the basis of the risk assessment (see Section 4.2). It highlights a holistic attribute of the morphological analysis when each element from one group of elements is analysed in connection to each element from the other group of elements. Each connection has a number which expresses a risk-based priority. It means that " $\mathrm{LH} / \mathrm{L}-\mathrm{O} 2$ " connection has the highest priority ("1") due to infrastructural risk calculated with the use of SFS data base (the highest risk). For the next example, the "F/S-O1" connection has the last priority in the analysed context (the lowest level of risk). The prioritization process allows us to emphasize connections which require the main attention in SIRE. Number of priorities depends on relevant merit-related assumptions of the analysis 
and the risk values (order of values, value differences, etc.), so it should be adapted to current cognitive needs and the risk assessment results. Taking into account all possible connections refers to a holistic, morphological mindset.

\begin{tabular}{|c|c|c|c|c|c|c|c|}
\hline \multicolumn{2}{|c|}{ Morphological analysis } & \multicolumn{6}{|c|}{ Categories of objects } \\
\hline & & $\mathrm{O} 1$ & $\mathrm{O} 2$ & O3 & $\mathrm{O} 4$ & O5 & O6 \\
\hline \multirow{9}{*}{ 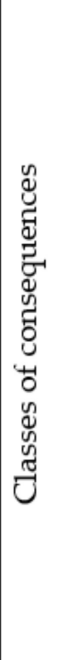 } & $\mathrm{F} / \mathrm{S}$ & 3 & 2 & 3 & 3 & 3 & 2 \\
\hline & $\mathrm{F} / \mathrm{M}$ & 3 & 3 & 3 & 3 & 3 & 3 \\
\hline & $\mathrm{F} / \mathrm{B}$ & 3 & 3 & 3 & 3 & 3 & 3 \\
\hline & $\mathrm{F} / \mathrm{VB}$ & 3 & 3 & 3 & 3 & 3 & 3 \\
\hline & $\mathrm{LH} / \mathrm{S}$ & 2 & 2 & 2 & 3 & 3 & 3 \\
\hline & $\mathrm{LH} / \mathrm{L}$ & 2 & 1 & 2 & 3 & 2 & 1 \\
\hline & $\mathrm{LH} / \mathrm{M}$ & 3 & 3 & 3 & 3 & 3 & 3 \\
\hline & $\mathrm{LH} / \mathrm{B}$ & 3 & 3 & 3 & 3 & 3 & 3 \\
\hline & $\mathrm{LH} / \mathrm{C}$ & 3 & 3 & 3 & 3 & 3 & 3 \\
\hline
\end{tabular}

Figure 3. Prioritization of connections "category of object-class of consequence". Source: own elaboration based on $[50,78]$.

The prioritization is crucial from the point of view of SIRE manners' formulation. The manners should be formulated for the riskiest connections in terms of all elements of the reference model for SIRE. Consequently, the holistic aspect will be considered and Gap 2 will be met. In addition, particular SIRE manners should be formulated on the basis of experts' knowledge.

\section{Results and Discussion}

\subsection{SIRE in Emergency Service Perspective}

As reference model for SIRE presents general directions to formulate relevant manners, the emergency service perspective can make them concrete in the light of protection of the most important, utilitarian values. This means an exact relation to life and health of the infrastructure users, safety of the infrastructure itself as well as safety of property and environment connected with the infrastructure if the connection may affect human life and health quality.

As one would expect, the described perspective evaluates a primary understanding of SIRE. The perspective forces us to take into consideration three issues [8,79]:

1. Hazards' character (common exposure to population, a wide spectrum of classes of consequences and cascading potential for development);

2. Operational specification (urgency, continuity and substitutability of tasks, operations and activities);

3. Resources requirements (adequacy, limitation and substitutability of resources).

This is why, in the context of emergency service, SIRE needs to be understood in terms of the following framework areas:

1. Physical resilience: infrastructure must be physically resilient for cascading development of societal hazards in entire spectrum of their consequences. Due to their complexity, substantial 
physical barriers to limit the hazards' access to infrastructure are required. In addition, human resources, which protect the infrastructure, should be ready to use different kinds of specialized equipment for this purpose.

2. Structure and setting resilience: owning to the mentioned interdependency, one's need to consider cascading connections in lines "hazard-Hazard", "hazard-Infrastructure" and "infrastructure-Infrastructure". Such way of thinking forces a necessity for multiresponse to natural disasters and man-made hazards. Consequently, a sufficient collaboration background is required to effectively face challenges in terms of the interentity protection process.

3. Organizational resilience: hazards affect organizations (e.g., infrastructure operator) and cause organizational threat occurrence. Thus, in analogy to the previous framework area, cascading connections between societal hazards and organizational threats must be considered. To ensure organizational resilience in relevant conditions, a system approach for the organization operation can be useful due to its complexity, complementarity and correspondence with external safety systems (e.g., SFRS). The system approach opens for creation of the response process with the use of multiple entities which have predominantly a positive effect on SIRE.

4. Economic resilience: the emergency specification shed a light into economic resilience of infrastructure operator, owner and/or supervisor (e.g., public administration authority). This is why the financial supply needs to be resilient from hazards' development (also when cascading effect materializes), ready for activation in terms of emergency circumstances. Furthermore, it should be based on economic establishment of operator, owner and/or supervisor, at the very least during the first response phase.

5. Legal resilience: urgency, which is typical for emergency status of infrastructure protection operations facing natural disasters and man-made hazards, is the opposite of the character of legal procedures and mechanisms. Nevertheless, the two must ensure that emergency-related acts are flexible. This means that loopholes and emergency legislation procedures are highly desirable. From a practical point of view, legal resilience should be equated with mechanisms to ensure flexibility of resources as well.

Considering the emergency service realm of SIRE, a relevant framework can be created. The framework is described in Table 5. Exemplary SIRE manners are formulated on the basis of the authors' knowledge and operational experiences in emergency and crisis management (incl. critical infrastructure protection) $[80,81]$.

Table 5. SIRE framework.

\begin{tabular}{ccll}
\hline No. & $\begin{array}{c}\text { RM-SIRE } \\
\text { Element }\end{array}$ & \multicolumn{1}{c}{ SIRE Framework Area } & \multicolumn{1}{c}{ Example of SIRE Manner } \\
\hline Physical & $\begin{array}{l}\text { 1.1. Physical resilience in terms of } \\
\text { cascading development of societal } \\
\text { hazards in entire spectrum of } \\
\text { consequences }\end{array}$ & $\begin{array}{l}\text { Additional protection systems (active or } \\
\text { passive) against hazards which occur in } \\
\text { neighbouring objects using few levels of } \\
\text { protection }\end{array}$ \\
\cline { 3 - 4 } & 1.2. Resilient physical barriers & $\begin{array}{l}\text { Substantial physical barriers limiting access to } \\
\text { infrastructure }\end{array}$ \\
\cline { 3 - 4 } & $\begin{array}{l}\text { 1.3. Physical-related flexibility of } \\
\text { resources }\end{array}$ & $\begin{array}{l}\text { Preparation of adequacy-equipped, different } \\
\text { entities }\end{array}$ \\
\hline \multirow{2}{*}{$\begin{array}{c}\text { Structure and } \\
\text { setting } \\
\text { resilience }\end{array}$} & $\begin{array}{l}\text { 2.1. Cascading connections } \\
\text { between hazards and } \\
\text { infrastructures }\end{array}$ & $\begin{array}{l}\text { Multiscenario continuity management of } \\
\text { different infrastructure operations (also the } \\
\text { infrastructure operators) }\end{array}$ \\
\cline { 3 - 4 } & 2.2. Multiresponse for hazards & $\begin{array}{l}\text { Response involvement of entities responsible } \\
\text { for protection interrelated infrastructures }\end{array}$ \\
\cline { 2 - 4 } & 2.3. Collaborative background & $\begin{array}{l}\text { Collaboration patterns and agreements } \\
\text { between infrastructure protection entities }\end{array}$ \\
\hline
\end{tabular}


Table 5. Cont.

\begin{tabular}{|c|c|c|c|}
\hline No. & $\begin{array}{l}\text { RM-SIRE } \\
\text { Element }\end{array}$ & SIRE Framework Area & Example of SIRE Manner \\
\hline \multirow{3}{*}{3} & \multirow{3}{*}{$\begin{array}{l}\text { Organizational } \\
\text { resilience }\end{array}$} & $\begin{array}{l}\text { 3.1. Cascading connections } \\
\text { between societal hazards and } \\
\text { organizational threats }\end{array}$ & $\begin{array}{l}\text { Multiscenario, risk-based emergency planning } \\
\text { for infrastructure protection }\end{array}$ \\
\hline & & $\begin{array}{l}\text { 3.2. System approach for } \\
\text { operation }\end{array}$ & $\begin{array}{l}\text { Development of substantiality in } \\
\text { organizational system operations }\end{array}$ \\
\hline & & $\begin{array}{l}\text { 3.3. Organizational-related } \\
\text { flexibility of resources }\end{array}$ & $\begin{array}{l}\text { Elaboration of organization mechanisms for } \\
\text { substitutable involvement of protection entities } \\
\text { into action and training evaluation of the } \\
\text { mechanism in the organization }\end{array}$ \\
\hline \multirow{3}{*}{4} & \multirow{3}{*}{$\begin{array}{l}\text { Economic } \\
\text { resilience }\end{array}$} & $\begin{array}{l}\text { 4.1. Financial resources resilient } \\
\text { from hazards' development }\end{array}$ & $\begin{array}{l}\text { Differentiation and diversification of financial } \\
\text { sources }\end{array}$ \\
\hline & & 4.2. Emergency economics & $\begin{array}{l}\text { Extra financial mechanism ready for emergency } \\
\text { activation }\end{array}$ \\
\hline & & $\begin{array}{l}\text { 4.3. Economic establishment of } \\
\text { resources }\end{array}$ & $\begin{array}{l}\text { Self-sufficiency of infrastructure protection } \\
\text { entities (incl. infrastructure operators) }\end{array}$ \\
\hline \multirow{3}{*}{5} & \multirow{3}{*}{ Legal resilience } & $\begin{array}{l}\text { 5.1. Legal flexibility for } \\
\text { preparation, response and } \\
\text { reconstruction }\end{array}$ & $\begin{array}{l}\text { Legal loopholes in acts concerning preparation, } \\
\text { response and reconstruction of infrastructure }\end{array}$ \\
\hline & & 5.2. Emergency legislation & $\begin{array}{l}\text { Extra legislation mechanism ready for } \\
\text { activation in terms of emergency conditions }\end{array}$ \\
\hline & & $\begin{array}{l}\text { 5.3. Legal background for } \\
\text { flexibility of resources }\end{array}$ & $\begin{array}{l}\text { Elaboration of legal mechanisms for } \\
\text { substitutable involvement of protection entities } \\
\text { into action }\end{array}$ \\
\hline
\end{tabular}

Source: own elaboration based on [80,81].

The framework shows concrete directions for relevant manners' formulation. Moreover, it can deliver input for additional and deeper analysis of infrastructure safety and emergency operations' efficacy. For example, risk analysis for cascading-related hazards and organizational threats, operational efficacy methods identification and efficiency cooperation analysis can be enumerated.

\subsection{Emergency Service Reception of Infrastructure Resilience (Risk Assessment)}

Emergency service perception of infrastructure resilience can be visualized by risk assessment which is based on SFS data base. Considering the voice of entities which operate in emergency conditions (direct danger to human life, time stress, etc.) allows for the consideration of a viewpoint of the most important, utilitarian values' protection and faces Gap 1.

SFS data base describes 1,255,826 events that occurred in 2015-2019 that affected the most important, utilitarian values (human life and health as well as property and environment in a scope of human survival needs). They are divided into 261,655 of F-events and 994,171 of LH-events [71].

Appendix A (Tables A1-A5) includes data about these events, respecting categories of infrastructural objects, classes of consequences and particular years of calculation. In addition, Table 6 presents summarized data for the events in the analysed time horizon. 
Table 6. Data summary for numbers of events in 2015-2019.

\begin{tabular}{cccccccc}
\hline \multirow{2}{*}{$C_{\boldsymbol{i}}$} & Class of Consequence $(\boldsymbol{i})$ & \multicolumn{7}{c}{ Category of Infrastructural Objects $(\boldsymbol{j})$} \\
\cline { 3 - 8 } & & $\mathbf{O 1}$ & $\mathbf{O 2}$ & $\mathbf{O 3}$ & $\mathbf{O 4}$ & O5 & O6 \\
\hline 1 & F/S & 11,763 & $1,53,580$ & 10,034 & 4191 & 9947 & 57,365 \\
2 & F/M & 394 & 4850 & 1495 & 793 & 4031 & 1556 \\
3 & F/B & 71 & 150 & 264 & 204 & 491 & 114 \\
4 & F/VB & 27 & 3 & 113 & 93 & 111 & 15 \\
& Totally: & 12,255 & 158,583 & 11,906 & 5281 & 14,580 & 59,050 \\
\hline 1 & LH/S & 28,955 & 86,399 & 2150 & 1326 & 1843 & 42,567 \\
2 & LH/L & 49,781 & 367,465 & 15,217 & 3478 & 23,639 & 364,246 \\
3 & LH/M & 955 & 3135 & 625 & 506 & 115 & 1599 \\
4 & LH/B & 29 & 42 & 23 & 8 & 3 & 61 \\
5 & LH/C & 0 & 4 & 0 & 0 & 0 & 0 \\
& Totally: & 79,720 & 457,045 & 18,015 & 5318 & 25,600 & 408,473 \\
\hline
\end{tabular}

Source: own elaboration.

Figure 4 visualizes the summary results below.

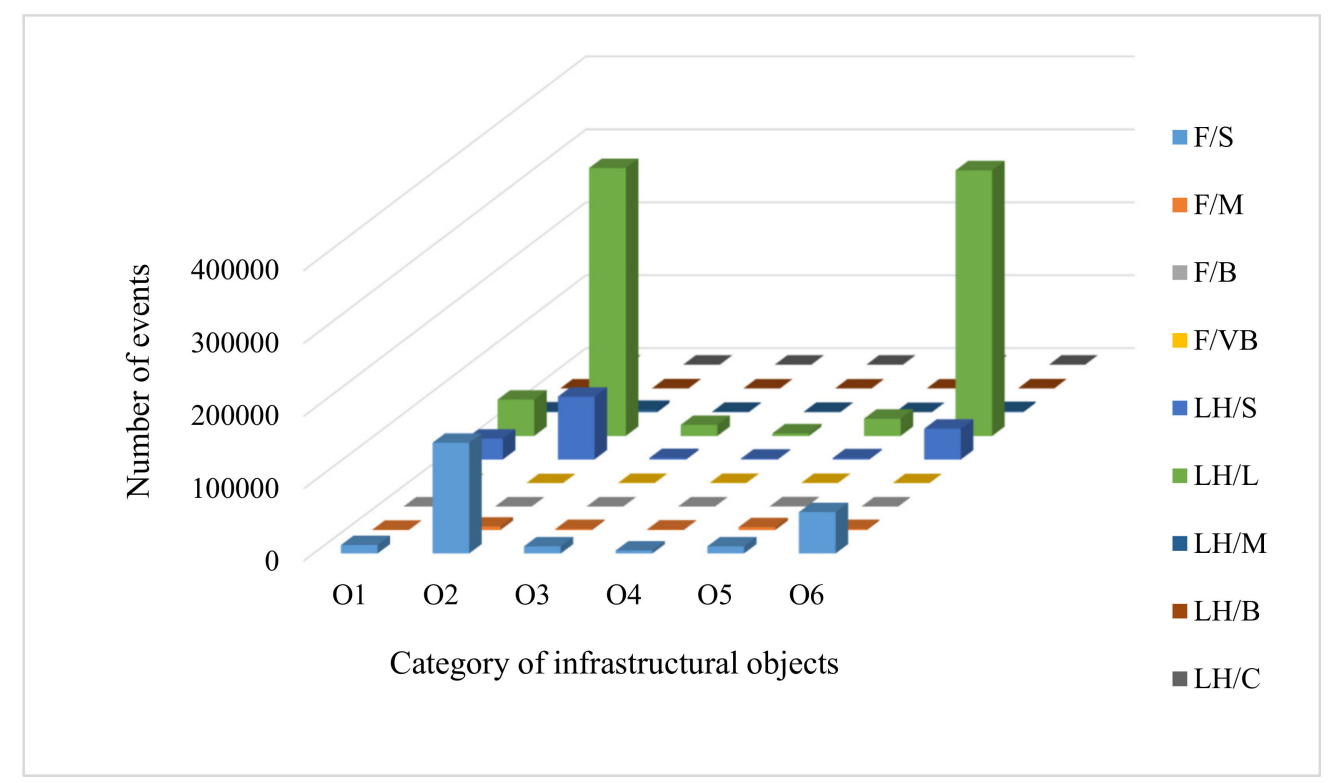

Figure 4. Data summary for numbers of events in 2015-2019. Source: own elaboration.

Two kinds of events stand out from the rest. These are LH/L-O2 and LH/L-O6. They commonly state $58 \%$ of a total number of events during the last five years. This means that surely most of the negatively perceived circumstances were related to urgent failures of machines, instruments, vehicles and other objects, which caused maximum one victim dead or maximum three victims supported by medical rescue teams (from outside SFRS) or required maximum four fire service teams'(12-24 rescuers) participation in the action. The circumstances occurred generally in residential objects and other objects. The next kind of event also concerns these categories of objects. F/S-O2 and F/S-O6 are noticed. This situation is expected from a general view into fire statistics and the hazard specification, when, a number of fires is inversely proportional to the class of consequences. Such trend can be a reason why LH/S-O2 events have relatively high influence on infrastructure safety.

In terms of the risk, use of Equation (1) gives input to Appendix B (Tables A6-A10) which includes data concerning risk indexes for particular categories of infrastructural objects in 2015-2019. In accordance with Equation (2), estimation of yearly-average risk indexes of $\mathrm{F} / \mathrm{LH}$ (for $i$-class of 
consequences and $j$-category of infrastructural objects) in 2015-2019 is possible. Table 7 presents a juxtaposition of the estimation results.

Table 7. Yearly-average F/LH-risk index for $i$-class of consequences and $j$-category of infrastructural objects in 2015-2019 ( $\left.\overline{R 2015-2019}_{(F / L H) i, j}\right)$.

\begin{tabular}{cccccccc}
\hline \multirow{2}{*}{$C_{i}$} & Class of Consequence $(\boldsymbol{i})$ & \multicolumn{7}{c}{ Category of Infrastructural Objects $(\boldsymbol{j})$} \\
\cline { 3 - 8 } & & $\mathbf{O 1}$ & $\mathbf{O 2}$ & $\mathbf{O 3}$ & $\mathbf{O 4}$ & O5 & O6 \\
\hline 1 & $\mathrm{~F} / \mathrm{S}$ & 2352.6 & 30,716 & 2006.8 & 838.2 & 1989.4 & 11473 \\
2 & $\mathrm{~F} / \mathrm{M}$ & 157.6 & 1940 & 598 & 317.2 & 1612.4 & 622.4 \\
3 & $\mathrm{~F} / \mathrm{B}$ & 42.6 & 90 & 158.4 & 122.4 & 294.6 & 68.4 \\
4 & $\mathrm{~F} / \mathrm{VB}$ & 21.6 & 2.4 & 90.4 & 74.4 & 88.8 & 12 \\
\hline 1 & $\mathrm{LH} / \mathrm{S}$ & 5791 & $17,279.8$ & 430 & 265.2 & 368.6 & 8513.4 \\
2 & $\mathrm{LH} / \mathrm{L}$ & $19,912.4$ & 146,986 & 6086.8 & 1391.2 & 9455.6 & $145,698.4$ \\
3 & $\mathrm{LH} / \mathrm{M}$ & 573 & 1881 & 375 & 303.6 & 69 & 959.4 \\
4 & $\mathrm{LH} / \mathrm{B}$ & 23.2 & 33.6 & 18.4 & 6.4 & 2.4 & 48.8 \\
5 & $\mathrm{LH} / \mathrm{C}$ & 0 & 4 & 0 & 0 & 0 & 0 \\
\hline
\end{tabular}

Figure 5 visualizes yearly-average F/LH-risk index distribution, considering classes of consequences and categories of infrastructural objects.

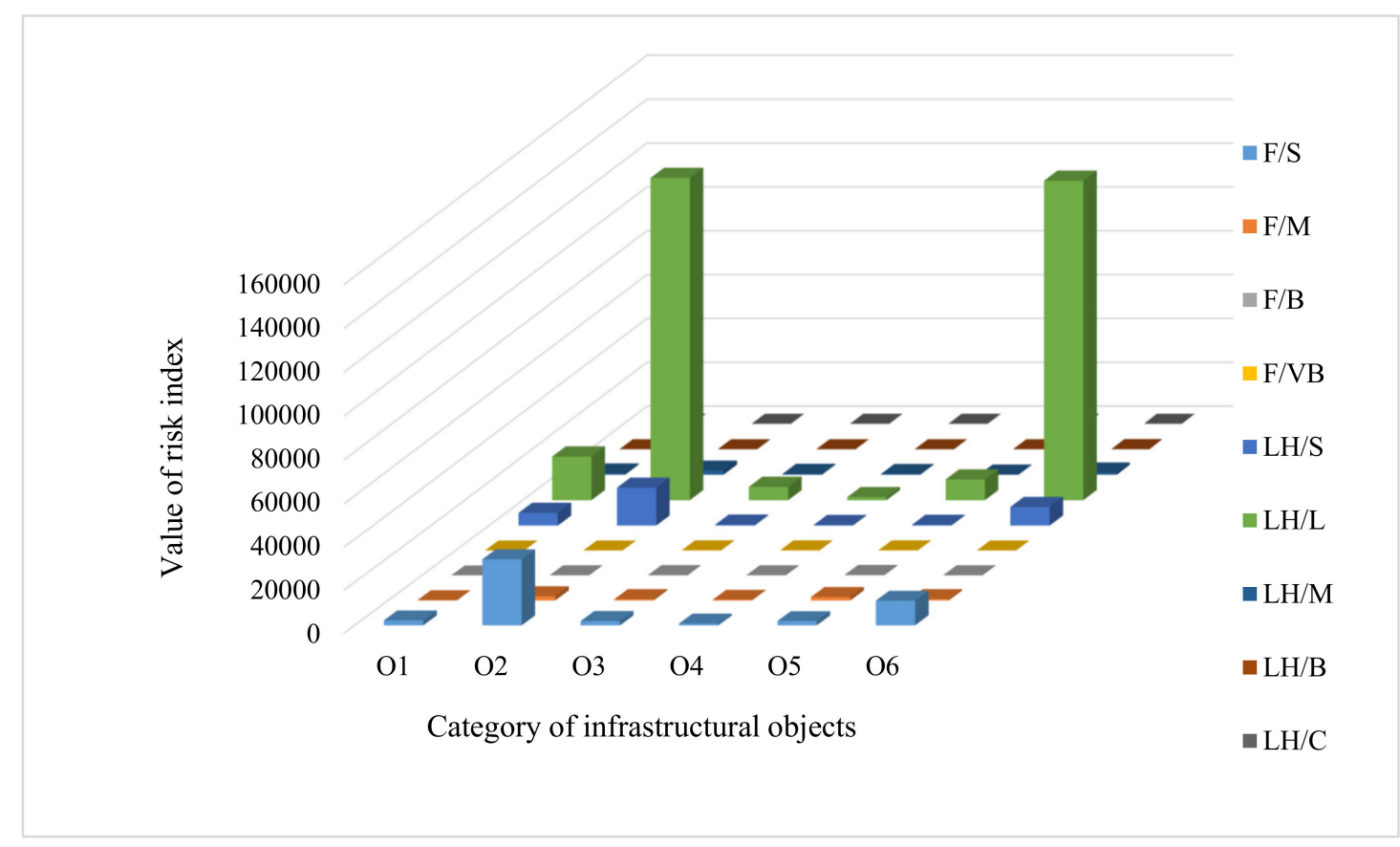

Figure 5. Yearly-average $\mathrm{F} / \mathrm{LH}$ risk indexes for $i$-class of consequences and $j$-category of infrastructural objects in 2015-2019 $\left(\overline{R 2015-2019}_{(F / L H) i, j}\right)$. Source: own elaboration.

In principle, risk assessment confirms previous results for number of events. The highest risk is calculated for LH/L-O2 and LH/L-O6. The two cover more than $69 \%$ of summary value of infrastructural risk. A risk-related distance between these kinds of events from other kinds of events increases because classes of consequences are taken into account.

Knowledge about actual risk levels due to hazards which effect the most important, utilitarian values creates the current picture for infrastructure safety. Information concerning the object trends is also valuable. Based on previous results, it is possible to get summary yearly F/LH-risk indexes 
for $i$-class of consequences and $j$-category of infrastructural object in the analysed years. These are compiled in Tables 8 and 9.

Table 8. Summary yearly F-risk indexes for $i$-class of consequences and $j$-category of infrastructural object in 2015-2019.

\begin{tabular}{ccccccc}
\hline RSY $_{(\boldsymbol{F}) \boldsymbol{i}, \boldsymbol{j}}$ & O1 & O2 & O3 & O4 & O5 & O6 \\
\hline 2015 & 2597 & 30,647 & 2931 & 1419 & 4902 & 13,048 \\
2016 & 2709 & 32,095 & 2772 & 1168 & 3743 & 10,999 \\
2017 & 2534 & 33,341 & 2655 & 1256 & 3503 & 10,239 \\
2018 & 2590 & 34,634 & 2995 & 1575 & 4027 & 12,856 \\
2019 & 2442 & 33,025 & 2915 & 1343 & 3751 & 13,737 \\
\hline
\end{tabular}

Source: own elaboration.

Table 9. Summary yearly LH-risk indexes for $i$-class of consequences and $j$-category of infrastructural object in 2015-2019.

\begin{tabular}{ccccccc}
\hline $\boldsymbol{R S Y}_{(\boldsymbol{L H}) \boldsymbol{i}, \boldsymbol{j}}$ & O1 & O2 & O3 & O4 & O5 & O6 \\
\hline 2015 & 23,441 & 138,809 & 6489 & 1535 & 9102 & 158,628 \\
2016 & 25,231 & 146,542 & 5886 & 1725 & 7658 & 148,439 \\
2017 & 26,760 & 176,390 & 7524 & 2157 & 11,503 & 203,527 \\
2018 & 26,860 & 195,067 & 8175 & 2243 & 13,583 & 122,867 \\
2019 & 29,206 & 174,114 & 6477 & 2172 & 7632 & 142,639 \\
\hline
\end{tabular}

Source: own elaboration.

Figures 6 and 7 present a time distribution of summary yearly F/LH-risk indexes. They show tendencies for infrastructural safety levels in accordance with the last five years.

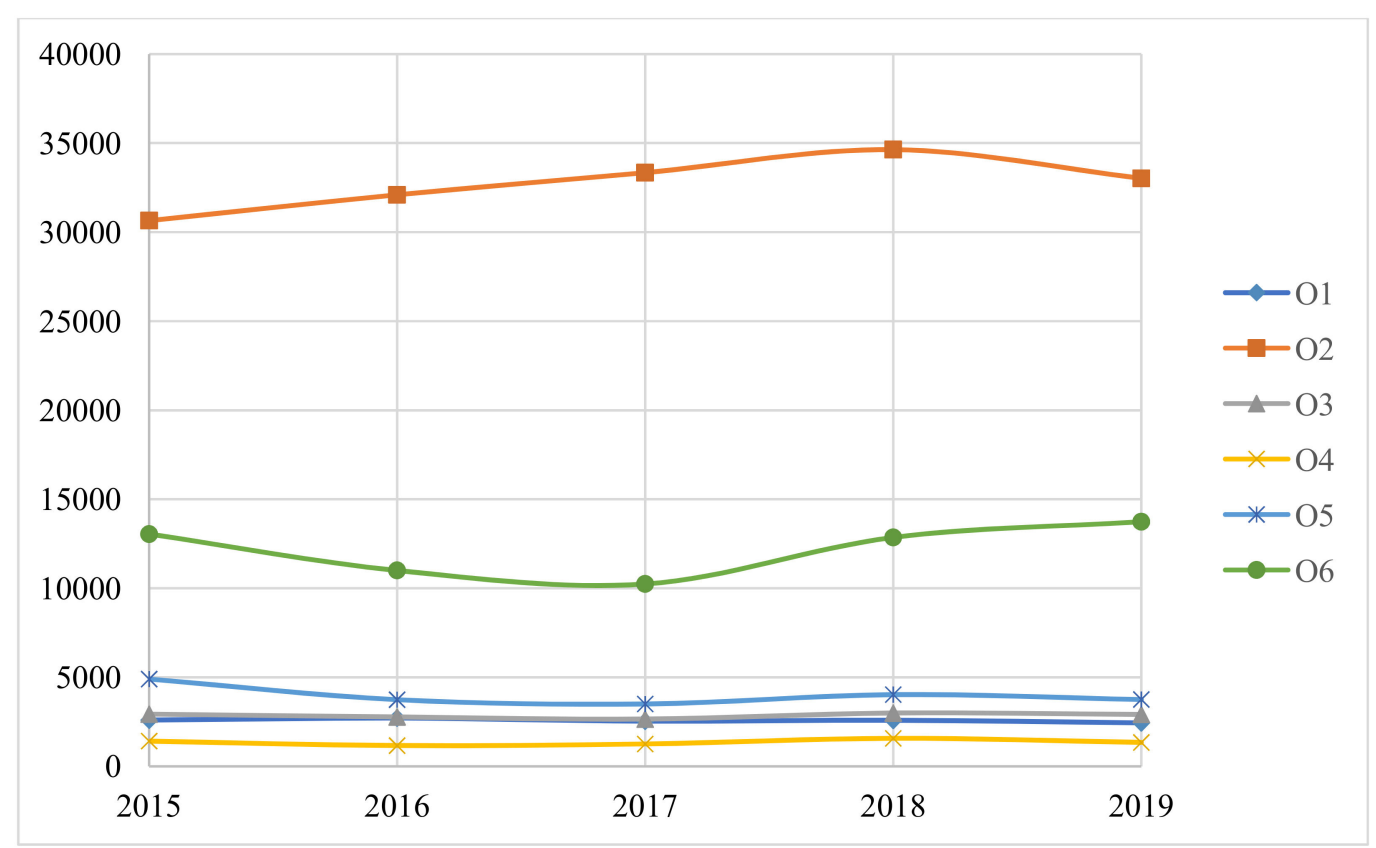

Figure 6. Summary yearly F-risk indexes for $i$-class of consequences and $j$-category of infrastructural object in 2015-2019. Source: own elaboration. 


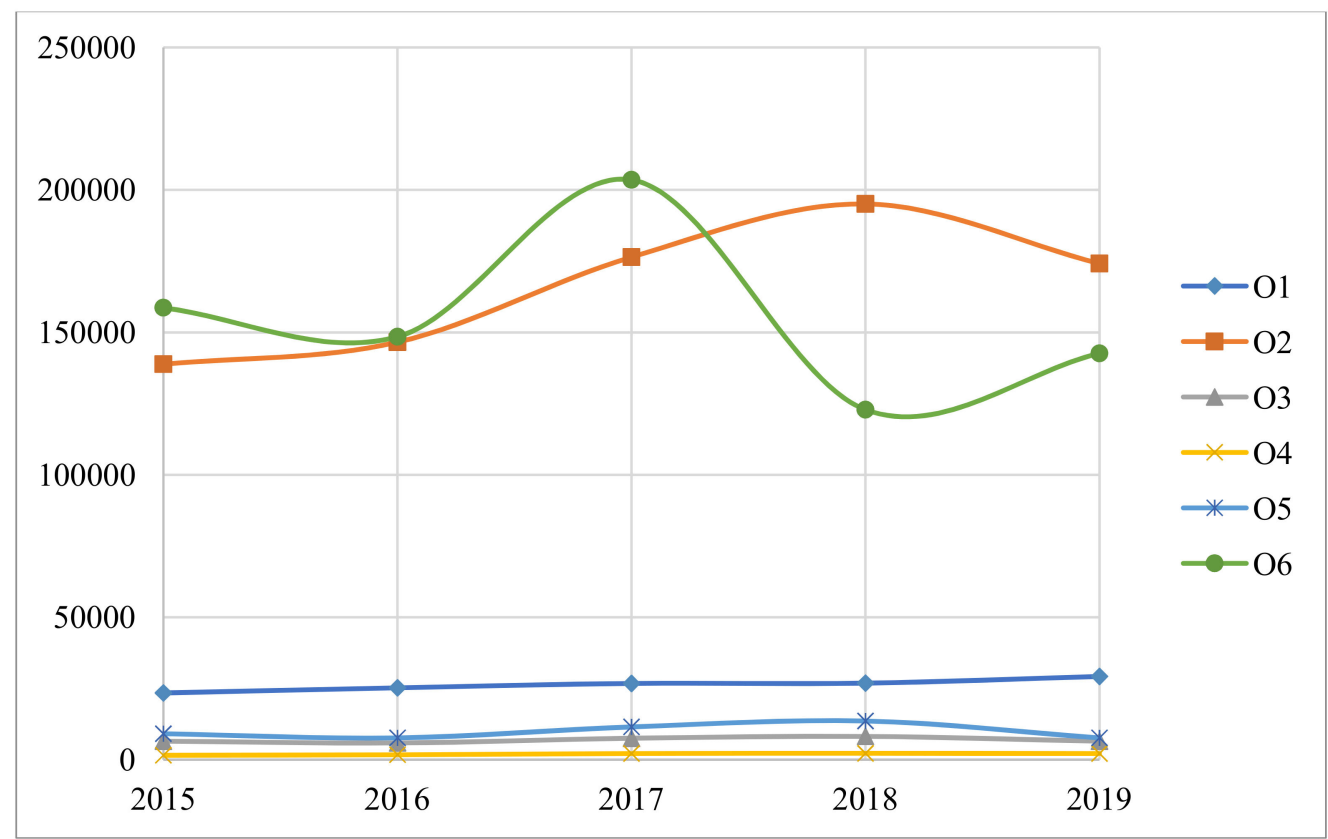

Figure 7. Summary yearly $L H$-risk indexes for $i$-class of consequences and $j$-category of infrastructural object in 2015-2019. Source: own elaboration.

Figure 7 shows the time-related distribution of summary yearly $L H$-risk indexes for $i$-class of consequences and $j$-category of infrastructural object.

As far as F-events are concerned, they all present stable levels of infrastructural safety. The highest risk for residential buildings $(\mathrm{O} 2)$ is noticed. It is more than two times higher than the risk level for the second category of objects (O6). The rest of the categories of objects are characterized by relatively low risk of fire in presented time perspective. In all cases an amplitude of changes is low and stable fire risk level for the infrastructure is expected.

Quite a different situation can be observed when LH-events are considered. Two tendency characteristics are identified. The first one comprises information for $\mathrm{O} 2$ and $\mathrm{O} 6$. The trends are dynamic, and difficult to predict in the coming years. Probably risk for $\mathrm{O} 2$ will decrease with apposite tendency for O6. The second characteristic is ascribed to the rest of the infrastructural objects. Their risk levels are clearly lower in comparison to $\mathrm{O} 2$ and O6. Furthermore, changes of amplitude are negligible and present a stable level of safety.

\subsection{Rationalization of SIRE Manners}

Rationalization of SIRE manners states a quintessence of the proposed methodology. It presents a mindset of emergency service and corresponds directly with the most important, utilitarian values (Gap 1). It connects multiple risk variants into one SIRE concept, filling Gap 2. In addition, the rationalization depends on risk assessment which uses real emergency data. Consequently, Gap 3 is taken into consideration.

Operationalizing, formulation of risk-rationalized SIRE manners requires a deepen exploration of final risk assessment results (see Figure 5 in Section 4.1). Vertical-horizontal analysis allows us to appoint three groups of infrastructures which holistically reflect risk assessment output:

1. High-risk infrastructure (LH/L-O2 and LH/L-O6) - Priority 1;

2. Medium-risk infrastructure (F/S-O2, F/S-O6, LH/S-O1, LH/S-O2, LH/S-O3, LH/L-O1, LH/L-O3 and LH/L-O5)-Priority 2;

3. Low-risk infrastructure (F/S-O1, F/S-O3, F/S-O4, F/S-O5, F/M-O1, F/M-O2, F/M-O3, F/M-O4, F/M-O5, F/M-O6, F/B-O1, F/B-O2, F/B-O3, F/B-O4, F/B-O5, F/B-O6; F/VB-O1, F/VB-O2, F/VB-O3, F/VB-O4, F/VB-O5, F/VB-O6; LH/S-O3, LH/S-O4, LH/S-O5, LH/L-O4, LH/M-O1，LH/M-O2, 
LH/M-O3, LH/M-O4, LH/M-O5, LH/M-O6, LH/B-O1, LH/B-O2, LH/B-O3, LH/B-O4, LH/B-O5, LH/B-O6, LH/C-O1, LH/C-O2, LH/C-O3, LH/C-O4, LH/C-O5 and LH/C-O6) - Priority 3.

Titles of the groups follow risk-related priorities ascribed to particular logical connections between classes of consequences and categories of objects. Most of cases relate to the last group. This fact highlights the two-extremes nature of the risk distribution. On the one site, there are objects mostly affected by hazards which influence the most important, utilitarian values (high-risk infrastructure). On the other site, there are the other categories of objects (medium-risk and low-risk ones). Differences between these two are clearly noticeable when the risk values are announced.

The rationalization essence states in formulation of manners only for the objects ascribed into the high-risk infrastructure (priority 1). The distance between the risk values related to the medium-risk group (priority 2) is so high that there is no risk-based reason to create the manners for other groups of infrastructures (for priority 2 and priority 3 ). As a logical consequence, risk-rationalized manners for SIRE are catalogued in Table 10 (for LH/L-O2) and Table 11 (for LH/L-O6).

Table 10. SIRE manners catalogue for LH/L-O2.

\begin{tabular}{|c|c|}
\hline SIRE Framework Area & SIRE Manners \\
\hline $\begin{array}{l}\text { 1.1. Physical resilience in terms of cascading } \\
\text { development of societal hazards in entire } \\
\text { spectrum of consequences }\end{array}$ & $\begin{array}{l}\text { Private protection systems (mainly the passive ones) against } \\
\text { urgent failures of machines, instruments, vehicles and other } \\
\text { objects which occur in the neighbourhood using few levels of } \\
\text { residential protection }\end{array}$ \\
\hline 1.2. Resilient physical barriers & $\begin{array}{l}\text { Locally-determined politics for residential building concerning } \\
\text { safe distances and physical barriers limiting access to local } \\
\text { infrastructure }\end{array}$ \\
\hline 1.3. Physical-related flexibility of resources & $\begin{array}{l}\text { Localization of temporary emergency units in residential areas } \\
\text { (e.g., fire unit and medical units using the same station) }\end{array}$ \\
\hline $\begin{array}{l}\text { 2.1. Cascading connections between hazards } \\
\text { and infrastructures }\end{array}$ & $\begin{array}{l}\text { Multiscenario continuity management of different processes } \\
\text { describing local society (power supply, water supply, access to } \\
\text { fuel and food, etc.) }\end{array}$ \\
\hline 2.2. Multiresponse for hazards & $\begin{array}{l}\text { Involvement of local society representatives in the response for } \\
\text { hazards (e.g., voluntary service) }\end{array}$ \\
\hline 2.3. Collaborative background & $\begin{array}{l}\text { Collaboration patterns and agreements between safety } \\
\text { institutions and voluntary groups, private individuals, etc. }\end{array}$ \\
\hline $\begin{array}{l}\text { 3.1. Cascading connections between societal } \\
\text { hazards and organizational threats }\end{array}$ & $\begin{array}{l}\text { Multiscenario, risk-based emergency planning for local society } \\
\text { protection with the use of the first disposal of emergency units }\end{array}$ \\
\hline 3.2. System approach for operation & $\begin{array}{l}\text { Education for safety to improve private potential to protect } \\
\text { residential objects }\end{array}$ \\
\hline $\begin{array}{l}\text { 3.3. Organizational-related flexibility of } \\
\text { resources }\end{array}$ & $\begin{array}{l}\text { Involvement of local society representatives into response } \\
\text { actions in } L H / L\end{array}$ \\
\hline $\begin{array}{l}\text { 4.1. Financial resources resilient from } \\
\text { hazards' development }\end{array}$ & $\begin{array}{l}\text { Differentiation and diversification of financial sources using } \\
\text { private and business supply sources in terms of } L H / L\end{array}$ \\
\hline 4.2. Emergency economics & $\begin{array}{l}\text { Local emergency funds as extra financial mechanism ready for } \\
\text { activation in case of necessity }\end{array}$ \\
\hline 4.3. Economic establishment of resources & Education to ensure economic self-sufficiency of local society \\
\hline $\begin{array}{l}\text { 5.1. Legal flexibility for preparation, } \\
\text { response and reconstruction }\end{array}$ & $\begin{array}{l}\text { Legal loopholes in general and local acts concerning } \\
\text { preparation, response and reconstruction of residential objects }\end{array}$ \\
\hline 5.2. Emergency legislation & $\begin{array}{l}\text { Extra legislation mechanism ready for activation in terms of } \\
\text { emergency conditions at lower levels of public administration }\end{array}$ \\
\hline $\begin{array}{l}\text { 5.3. Legal background for flexibility of } \\
\text { resources }\end{array}$ & $\begin{array}{l}\text { Elaboration of legal mechanisms for substitutable involvement } \\
\text { of individuals }\end{array}$ \\
\hline
\end{tabular}


Table 11. SIRE manners catalogue for LH/L-O6.

\begin{tabular}{|c|c|}
\hline SIRE Framework Area & SIRE Manners \\
\hline $\begin{array}{l}\text { 1.1. Physical resilience in terms of cascading } \\
\text { development of societal hazards in entire } \\
\text { spectrum of consequences }\end{array}$ & $\begin{array}{l}\text { Private and business protection systems (active and passive } \\
\text { ones) against urgent failures of machines, instruments, vehicles } \\
\text { and other objects which occur in neighbourhood using few } \\
\text { levels of private and business protection }\end{array}$ \\
\hline 1.2. Resilient physical barriers & $\begin{array}{l}\text { General politics for building which concern safe distances and } \\
\text { physical barriers limiting access to untypical infrastructures }\end{array}$ \\
\hline 1.3. Physical-related flexibility of resources & $\begin{array}{l}\text { Localization of temporary emergency units in areas where } \\
\text { untypical objects are localized }\end{array}$ \\
\hline $\begin{array}{l}\text { 2.1. Cascading connections between hazards } \\
\text { and infrastructures }\end{array}$ & $\begin{array}{l}\text { Multiscenario continuity management of different processes } \\
\text { describing untypical objects and their connection with local } \\
\text { society (accordingly to power supply, water supply, access to } \\
\text { fuel and food, etc.) }\end{array}$ \\
\hline 2.2. Multiresponse for hazards & $\begin{array}{l}\text { Involvement of infrastructure operators in the response for } \\
\text { hazards (e.g., military fire service) }\end{array}$ \\
\hline 2.3. Collaborative background & $\begin{array}{l}\text { Collaboration patterns and agreements between safety } \\
\text { institutions and untypical infrastructure operators/owners }\end{array}$ \\
\hline $\begin{array}{l}\text { 3.1. Cascading connections between societal } \\
\text { hazards and organizational threats }\end{array}$ & $\begin{array}{l}\text { Multiscenario, risk-based emergency planning for local society } \\
\text { protection and for business with the use of the first disposal of } \\
\text { emergency units }\end{array}$ \\
\hline 3.2. System approach for operation & $\begin{array}{l}\text { Education for safety to improve operators' potential to protect } \\
\text { their objects as well as common trainings with emergency units }\end{array}$ \\
\hline $\begin{array}{l}\text { 3.3. Organizational-related flexibility of } \\
\text { resources }\end{array}$ & $\begin{array}{l}\text { Involvement of infrastructure operators into response actions } \\
\text { in LH/L }\end{array}$ \\
\hline $\begin{array}{l}\text { 4.1. Financial resources resilient from } \\
\text { hazards' development }\end{array}$ & $\begin{array}{l}\text { Differentiation and diversification of financial sources using } \\
\text { private, business and public supply sources in terms of LH/L }\end{array}$ \\
\hline 4.2. Emergency economics & $\begin{array}{l}\text { Public and local emergency funds as extra financial mechanism } \\
\text { ready for activation in case of necessity }\end{array}$ \\
\hline 4.3. Economic establishment of resources & Self-sufficiency of infrastructure operators \\
\hline $\begin{array}{l}\text { 5.1. Legal flexibility for preparation, } \\
\text { response and reconstruction }\end{array}$ & $\begin{array}{l}\text { Legal loopholes in general and local acts concerning } \\
\text { preparation, response and reconstruction of untypical objects }\end{array}$ \\
\hline 5.2. Emergency legislation & $\begin{array}{l}\text { Extra legislation mechanism ready for activation in terms of } \\
\text { emergency conditions at all levels of public administration }\end{array}$ \\
\hline $\begin{array}{l}\text { 5.3. Legal background for flexibility of } \\
\text { resources }\end{array}$ & $\begin{array}{l}\text { Elaboration of legal mechanisms for substitutable involvement } \\
\text { of emergency support from other public institutions, voluntary } \\
\text { groups and business representatives }\end{array}$ \\
\hline
\end{tabular}

Source: own elaboration based on [80,81].

\section{Conclusions}

Infrastructure resilience reflects the current sustainable-related direction of the developing world. SIRE can be done with the use of multiple different approaches and tools. Among them are the most important, utilitarian values (human life and health as well as property and environment in a scope of human survival needs) which are worth emphasising. From the quality point of view, SIRE should be based on real data and risk is desirable as a safety measure and factor which determines relevant manners' rationalization. Moreover, emergency service data is significantly needed.

In the analysed context, infrastructure sustainability is an ability of the infrastructural dimension of the city (urban area) to improve the quality of inhabitants' life as well as the efficiency of urban services and operation. This is closely related to infrastructure resilience, which can be defined as the capacity to withstand in the case of, desirably, a whole spectrum of stresses and shocks (including natural disasters and man-made hazards). The relation between sustainability and resilience in terms of 
SIRE is bidirectional. Sustainability can influence the system (community, infrastructure, city) resilience and resilience may determine the system sustainability. Precisely, direct and indirect associations with SDG9, SDG11 and SDG13 are noticed. Moreover, sustainability can constitute a comprehensive framework for SIRE, order multiple resilience variants and create coherent notion of SIRE. The very important method for rationalizing all potential directions for SIRE is risk assessment. Its practical implementation allows us to express the mindset of entities that protect the most important, utilitarian values, and consequently priorities analysis areas for SIRE. Due to the priority-oriented direction of research, the results do not give an answer for a question about resilience levels for evaluated objects. It is based on the assumption that very resilient objects can be significantly affected by serious and/or numerus hazards. The high resilience level does not imply simultaneously low risk level. Therefore, from the emergency service point of view, risk awareness influences knowledge about directions to increase the resilience. Consequently, risk assessment can be used for SIRE rationalization.

SIRE model comprises five elements: physical resilience, structure and setting resilience, organizational resilience, economic resilience and legal resilience. When issues which determine the risk assessment perspective (the emergency one) are taken into consideration, one can formulate SIRE framework. Thus, the framework elements (SIRE manners) should concern common exposure for population to hazards, wide spectrum of classes of consequences and cascading potential for the hazards' development, urgency, continuity and substitutability of tasks, operations and activities as well as adequacy, limitation and substitutability of resources. It is worth highlighting the model cognitive potential, because its universality and comprehensiveness open many SIRE mindsets (not only the emergency service one).

Risk assessment is a tool for building situational awareness in terms of infrastructure safety levels related to natural disasters and man-made hazards. In accordance with SFS data base, the tool is built on four classes of consequences for fires and five classes of consequences for negative phenomena that are not fires and state danger to people, property or environment, resulting from civilization development, people operations or natural disasters. Residential buildings and other categories of objects in the light of locally-limited local hazards (LH/L-O2 and LH/L-O6) are categories of infrastructural objects connected to the highest number of events in 2015-2019 (58\% of the total number of events in the analysed period of time). These numbers correspond with infrastructural risk values (more than $69 \%$ of summary value of infrastructural risk). Furthermore, trend analysis allows us to assume that these values and risk differences between particular categories of objects and particular classes of consequences will be generally approximate in value during the coming years (with the exception of the above-mentioned LH/L-O2 and LH/L-O6). The 2015-2019 period of time refers to the last events documented by SFS in the data base. It is sufficiently long to identify a general view into the infrastructure risk profile. In addition, relevant data analysis allows for preliminary determination of trends. Further research for the previous and next periods of time are said to be a proper way for monitoring of the infrastructure risk situation, increasing the trends' relevancy and making the risk awareness more reliable.

All these issues shape SIRE manners at the stage of their risk-based rationalization. Risk assessment results allow to enumerate three groups of infrastructures. Owing to the two-extremes nature of the risk distribution, it is justified to focus on the high-risk infrastructure. So, sustainable BRI manners should be formulated only for LH/L-O2 and LH/L-O6. This does not mean a full acceptation for other cases but rather shows which of them needs the main attention and which can be just monitored (with the use of such classical risk treatment manners as acceptation, transfer, reduction, etc).

Deepening analysis of SIRE manners for a risk-limited number of cases gives information about their specification. In general, they can be formulated using top-down and bottom-up approaches. In the top-down direction, mostly institutional collaboration mechanisms, flexible legal solutions and common infrastructure protection awareness are noticed. Relevant information can be valuable especially for public administration, public services as well as institutional infrastructure operators, owners and supervisors. From the bottom-up mindset, the most complex user group is considered, 
namely individuals and social groups responsible for residential buildings. The SIRE model allows us to connect these two perspectives into the SIRE in a holistic way. In addition, it gives practical guidelines for decision makers who create national and local infrastructure politics, collaboration mechanisms and educational programs and have influence on incentive solutions (tax concessions, insurance benefits, etc.) - both crucial for SIRE effectiveness.

In conclusion, all research objectives are achieved. However, relevant limitations and directions for further research need to be described. First of all, SDG9, SDG11 and SDG13 introduce the research but also reduce the cognitive perception. They mostly refer to the infrastructure resilience, for sure. However, analysis for other SDGs can be useful for identification of untypical and unobvious SIRE determinants. Secondly, the emergency perspective limits kinds of hazards to fires and negative phenomena that are not fires and state danger to people, property or environment, resulting from civilization development, people operations or natural disasters. Furthermore, it strongly determines understanding of particular classes of consequences, boiling it down to the size of the hazard zone, information about victims and emergency resources dispatched to the action. Even if this context seems to be the most appropriate for SIRE affected by the most serious events, other contexts are worth investigating (e.g., Police, insurance institutions, critical infrastructure operators) to deepen exploration of this area of knowledge. Thirdly, the rationalization process is based only on the risk assessment, as the risk is a very objective safety measure. Ex ante and ex post analysis of SIRE manners will allow us to answer questions for their foreseen and real effectiveness and will open practical knowledge by a description of concrete case studies.

The paper contributes to sustainability knowledge by a proposition of a novel approach for SIRE which reflects direct protection of the most important values (human life and health) in emergency service mindset. Unique connection of sustainability, resilience and risk is described. A rarely described point of view (emergency service) is expressed. These issues can give a new quality to sustainability research. They prove that sustainability can be simultaneously a research objective and research tool to achieve this objective. Universality of this conclusion could have a significant influence on other areas of interest for sustainability theoreticians and practitioners.

Author Contributions: Conceptualization: P.G.; Methodology: P.G.; Validation: G.S. and P.G.; Formal Analysis: G.S.; Investigation: P.G. and G.S.; Resources: P.G.; Data Curation: P.G.; Writing-Original Draft Preparation: P.G.; Writing—Review \& Editing: G.S. and P.G.; Visualization: P.G.; Supervision: G.S.; Project Administration: P.G.; Funding Acquisition: P.G. All authors have read and agreed to the published version of the manuscript.

Funding: This research was funded by the Main School of Fire Service in Warsaw (Poland) grant number RN.7010.1.2020.

Acknowledgments: Authors would like to express their gratitude to the Main School of Fire Service in Warsaw (Poland) for financial support of the research. The support was ensured from the internal fund for research development. It was based on financial support from the Ministry of Interior and Administration of the Republic of Poland.

Conflicts of Interest: The authors declare no conflict of interest.

\section{Appendix A}

Data about numbers of events that occurred in 2015-2019.

Table A1. Numbers of events in 2015.

\begin{tabular}{cccccccc}
\hline \multirow{2}{*}{$C_{i}$} & Class of Consequence $(i)$ & \multicolumn{7}{c}{ Category of Infrastructural Objects $(j)$} \\
\cline { 3 - 7 } & & O1 & O2 & O3 & O4 & O5 & O6 \\
\hline 1 & F/S & 2336 & 28,481 & 2020 & 891 & 2263 & 12,324 \\
2 & F/M & 109 & 1035 & 324 & 167 & 1045 & 321 \\
3 & F/B & 9 & 32 & 61 & 42 & 139 & 22 \\
4 & F/VB & 4 & 0 & 20 & 17 & 33 & 4 \\
& Totally: & 2458 & 29,548 & 2425 & 1117 & 3480 & 12671 \\
\hline
\end{tabular}


Table A1. Cont.

\begin{tabular}{cccccccc}
\hline \multirow{2}{*}{$C_{\boldsymbol{i}}$} & Class of Consequence $(\boldsymbol{i})$ & \multicolumn{7}{c}{ Category of Infrastructural Objects $(\boldsymbol{j})$} \\
\cline { 3 - 8 } & & $\mathbf{O 1}$ & $\mathbf{O 2}$ & $\mathbf{O 3}$ & $\mathbf{O 4}$ & $\mathbf{O 5}$ & $\mathbf{O 6}$ \\
\hline 1 & LH/S & 5498 & 14,582 & 396 & 201 & 727 & 10,134 \\
2 & LH/L & 8789 & 61,510 & 2903 & 554 & 4165 & 73,934 \\
3 & LH/M & 115 & 388 & 89 & 74 & 15 & 202 \\
4 & LH/B & 5 & 7 & 5 & 1 & 0 & 5 \\
5 & LH/C & 0 & 3 & 0 & 0 & 0 & 0 \\
& Totally: & 14,407 & 76,490 & 3393 & 830 & 4907 & 84,275 \\
\hline
\end{tabular}

Source: own elaboration based on [71].

Table A2. Numbers of events in 2016.

\begin{tabular}{|c|c|c|c|c|c|c|c|}
\hline \multirow{2}{*}{$C_{i}$} & \multirow{2}{*}{ Class of Consequence (i) } & \multicolumn{6}{|c|}{ Category of Infrastructural Objects $(j)$} \\
\hline & & O1 & $\mathrm{O} 2$ & O3 & $\mathrm{O} 4$ & O5 & O6 \\
\hline 1 & $\mathrm{~F} / \mathrm{S}$ & 2511 & 30,198 & 1934 & 720 & 1883 & 10,398 \\
\hline 2 & $\mathrm{~F} / \mathrm{M}$ & 70 & 903 & 302 & 132 & 785 & 258 \\
\hline 3 & $\mathrm{~F} / \mathrm{B}$ & 14 & 29 & 46 & 36 & 74 & 23 \\
\hline \multirow{2}{*}{4} & $\mathrm{~F} / \mathrm{VB}$ & 4 & 1 & 24 & 19 & 17 & 4 \\
\hline & Totally: & 2599 & 31,131 & 2306 & 907 & 2759 & 10,683 \\
\hline 1 & $\mathrm{LH} / \mathrm{S}$ & 6375 & 14,894 & 385 & 189 & 256 & 8102 \\
\hline 2 & $\mathrm{LH} / \mathrm{L}$ & 9215 & 65,187 & 2613 & 670 & 3684 & 69,805 \\
\hline 3 & $\mathrm{LH} / \mathrm{M}$ & 134 & 418 & 85 & 64 & 10 & 237 \\
\hline 4 & $\mathrm{LH} / \mathrm{B}$ & 6 & 5 & 5 & 1 & 1 & 4 \\
\hline \multirow[t]{2}{*}{5} & LH/C & 0 & 0 & 0 & 0 & 0 & 0 \\
\hline & Totally: & 15,730 & 80,504 & 3088 & 924 & 3951 & 78,148 \\
\hline
\end{tabular}

Source: own elaboration based on [71]

Table A3. Numbers of events in 2017.

\begin{tabular}{cccccccc}
\hline \multirow{2}{*}{$C_{i}$} & \multirow{2}{*}{ Class of Consequence $(\boldsymbol{i})$} & \multicolumn{7}{c}{ Category of Infrastructural Objects $(\boldsymbol{j})$} \\
\cline { 3 - 8 } & & $\mathbf{O 1}$ & $\mathbf{O 2}$ & $\mathbf{O 3}$ & $\mathbf{O 4}$ & O5 & O6 \\
\hline 1 & F/S & 2332 & 31,461 & 1933 & 807 & 1805 & 9655 \\
2 & F/M & 67 & 902 & 261 & 145 & 695 & 254 \\
3 & F/B & 16 & 24 & 40 & 29 & 80 & 24 \\
4 & F/VB & 5 & 1 & 20 & 18 & 17 & 1 \\
& Totally: & 2420 & 32,388 & 2254 & 999 & 2597 & 9934 \\
\hline 1 & LH/S & 5426 & 17,325 & 423 & 282 & 310 & 9420 \\
2 & LH/L & 10,316 & 78,584 & 3384 & 803 & 5536 & 96,478 \\
3 & LH/M & 222 & 624 & 103 & 87 & 39 & 357 \\
4 & LH/B & 9 & 5 & 6 & 2 & 1 & 20 \\
5 & LH/C & 0 & 1 & 0 & 0 & 0 & 0 \\
& Totally: & 15,973 & 96,539 & 3916 & 1174 & 5886 & 106,275 \\
\hline
\end{tabular}

Source: own elaboration based on [71]. 
Table A4. Numbers of events in 2018.

\begin{tabular}{cccccccc}
\hline \multirow{2}{*}{$\boldsymbol{C}_{\boldsymbol{i}}$} & \multirow{2}{*}{ Class of Consequence $(\boldsymbol{i})$} & \multicolumn{7}{c}{ Category of Infrastructural Objects $(\boldsymbol{j})$} \\
\cline { 3 - 8 } & & $\mathbf{O 1}$ & $\mathbf{O 2}$ & $\mathbf{O 3}$ & $\mathbf{O 4}$ & O5 & O6 \\
\hline 1 & $\mathrm{~F} / \mathrm{S}$ & 2344 & 32,443 & 2124 & 946 & 2049 & 12,141 \\
2 & $\mathrm{~F} / \mathrm{M}$ & 75 & 1046 & 298 & 175 & 802 & 323 \\
3 & F/B & 20 & 33 & 61 & 57 & 98 & 19 \\
4 & F/VB & 9 & 0 & 23 & 27 & 20 & 3 \\
& Totally: & 2448 & 33,522 & 2506 & 1205 & 2969 & 12,486 \\
\hline 1 & LH/S & 5055 & 18,928 & 484 & 389 & 277 & 7111 \\
2 & LH/L & 10,622 & 86,896 & 3593 & 738 & 6623 & 57,353 \\
3 & LH/M & 183 & 769 & 163 & 122 & 20 & 342 \\
4 & LH/B & 3 & 10 & 4 & 3 & 0 & 6 \\
5 & LH/C & 0 & 0 & 0 & 0 & 0 & 0 \\
& Totally: & 15,863 & 106,603 & 4244 & 1252 & 6920 & 64,812 \\
\hline
\end{tabular}

Source: own elaboration based on [71]

Table A5. Numbers of events in 2019.

\begin{tabular}{cccccccc}
\hline \multirow{2}{*}{$C_{i}$} & \multirow{2}{*}{ Class of Consequence $(\boldsymbol{i})$} & \multicolumn{7}{c}{ Category of Infrastructural Objects $(\boldsymbol{j})$} \\
\cline { 3 - 8 } & & O1 & O2 & O3 & O4 & O5 & O6 \\
\hline 1 & F/S & 2240 & 30,997 & 2023 & 827 & 1947 & 12,847 \\
2 & F/M & 73 & 964 & 310 & 174 & 704 & 400 \\
3 & F/B & 12 & 32 & 56 & 40 & 100 & 26 \\
4 & F/VB & 5 & 1 & 26 & 12 & 24 & 3 \\
& Totally: & 2330 & 31,994 & 2415 & 1053 & 2775 & 13,276 \\
\hline 1 & LH/S & 6601 & 20,670 & 462 & 265 & 273 & 7800 \\
2 & LH/L & 10,839 & 75,288 & 2724 & 713 & 3631 & 66,676 \\
3 & LH/M & 301 & 936 & 185 & 159 & 31 & 461 \\
4 & LH/B & 6 & 15 & 3 & 1 & 1 & 26 \\
5 & LH/C & 0 & 0 & 0 & 0 & 0 & 0 \\
& Totally: & 17,747 & 96,909 & 3374 & 1138 & 3936 & 74,963 \\
\hline
\end{tabular}

Source: own elaboration based on [71].

\section{Appendix B}

Risk indexes for particular categories of infrastructural objects in 2015-2019.

Table A6. Risk indexes for particular categories of infrastructural objects in $2015\left(R 2015_{(F / L H) i, j}\right)$.

\begin{tabular}{cccccccc}
\hline \multirow{2}{*}{$C_{i}$} & \multirow{2}{*}{ Class of Consequence $(\boldsymbol{i})$} & \multicolumn{6}{c}{ Category of Infrastructural Objects $(\boldsymbol{j})$} \\
\cline { 3 - 8 } & & $\mathbf{O 1}$ & $\mathbf{O 2}$ & $\mathbf{O 3}$ & $\mathbf{O 4}$ & $\mathbf{O 5}$ & O6 \\
\hline 1 & $\mathrm{~F} / \mathrm{S}$ & 2336 & 28,481 & 2020 & 891 & 2263 & 12,324 \\
2 & $\mathrm{~F} / \mathrm{M}$ & 218 & 2070 & 648 & 334 & 2090 & 642 \\
3 & $\mathrm{~F} / \mathrm{B}$ & 27 & 96 & 183 & 126 & 417 & 66 \\
4 & F/VB & 16 & 0 & 80 & 68 & 132 & 16 \\
& Totally: & 2597 & 30,647 & 2931 & 1419 & 4902 & 13,048 \\
\hline 1 & LH/S & 5498 & 14,582 & 396 & 201 & 727 & 10,134 \\
2 & LH/L & 17,578 & 123,020 & 5806 & 1108 & 8330 & 147,868 \\
3 & LH/M & 345 & 1164 & 267 & 222 & 45 & 606 \\
4 & LH/B & 20 & 28 & 20 & 4 & 0 & 20 \\
5 & LH/C & 0 & 15 & 0 & 0 & 0 & 0 \\
& Totally: & 23,441 & 138,809 & 6489 & 1535 & 9102 & 158,628 \\
\hline
\end{tabular}


Table A7. Risk indexes for particular categories of infrastructural objects in $2016\left(R 2016_{(F / L H) i, j}\right)$.

\begin{tabular}{cccccccc}
\hline \multirow{2}{*}{$C_{\boldsymbol{i}}$} & Class of Consequence $(\boldsymbol{i})$ & \multicolumn{7}{c}{ Category of Infrastructural Objects $(\boldsymbol{j})$} \\
\cline { 3 - 8 } & & $\mathbf{O 1}$ & $\mathbf{O 2}$ & $\mathbf{O 3}$ & $\mathbf{O 4}$ & O5 & O6 \\
\hline 1 & F/S & 2511 & 30,198 & 1934 & 720 & 1883 & 10,398 \\
2 & F/M & 140 & 1806 & 604 & 264 & 1570 & 516 \\
3 & F/B & 42 & 87 & 138 & 108 & 222 & 69 \\
4 & F/VB & 16 & 4 & 96 & 76 & 68 & 16 \\
& Totally: & 2709 & 32,095 & 2772 & 1168 & 3743 & 10,999 \\
\hline 1 & LH/S & 6375 & 14,894 & 385 & 189 & 256 & 8102 \\
2 & LH/L & 18,430 & 130,374 & 5226 & 1340 & 7368 & 139,610 \\
3 & LH/M & 402 & 1254 & 255 & 192 & 30 & 711 \\
4 & LH/B & 24 & 20 & 20 & 4 & 4 & 16 \\
5 & LH/C & 0 & 0 & 0 & 0 & 0 & 0 \\
& Totally: & 25,231 & 146,542 & 5886 & 1725 & 7658 & 148,439 \\
\hline
\end{tabular}

Table A8. Risk indexes for particular categories of infrastructural objects in $2017\left(R 2017_{(F / L H) i, j}\right)$.

\begin{tabular}{cccccccc}
\hline \multirow{2}{*}{$C_{i}$} & Class of Consequence $(i)$ & \multicolumn{7}{c}{ Category of Infrastructural Objects $(\boldsymbol{j})$} \\
\cline { 3 - 8 } & & $\mathbf{O 1}$ & $\mathbf{O 2}$ & $\mathbf{O 3}$ & $\mathbf{O 4}$ & $\mathbf{O 5}$ & $\mathbf{O 6}$ \\
\hline 1 & $\mathrm{~F} / \mathrm{S}$ & 2332 & 31,461 & 1933 & 807 & 1805 & 9655 \\
2 & $\mathrm{~F} / \mathrm{M}$ & 134 & 1804 & 522 & 290 & 1390 & 508 \\
3 & $\mathrm{~F} / \mathrm{B}$ & 48 & 72 & 120 & 87 & 240 & 72 \\
4 & F/VB & 20 & 4 & 80 & 72 & 68 & 4 \\
& Totally: & 2534 & 33,341 & 2655 & 1256 & 3503 & 10,239 \\
\hline 1 & LH/S & 5426 & 17,325 & 423 & 282 & 310 & 9420 \\
2 & LH/L & 20,632 & 157,168 & 6768 & 1606 & 11,072 & 192,956 \\
3 & LH/M & 666 & 1872 & 309 & 261 & 117 & 1071 \\
4 & LH/B & 36 & 20 & 24 & 8 & 4 & 80 \\
5 & LH/C & 0 & 5 & 0 & 0 & 0 & 0 \\
& Totally: & 26,760 & 176,390 & 7524 & 2157 & 11,503 & 203,527 \\
\hline
\end{tabular}

Source: own elaboration.

Table A9. Risk indexes for particular categories of infrastructural objects in $2018\left(R 2018_{(F / L H) i, j}\right)$.

\begin{tabular}{cccccccc}
\hline \multirow{2}{*}{$C_{i}$} & Class of Consequence $(i)$ & \multicolumn{7}{c}{ Category of Infrastructural Objects $(j)$} \\
\cline { 3 - 8 } & & O1 & O2 & O3 & O4 & O5 & O6 \\
\hline 1 & F/S & 2344 & 32,443 & 2124 & 946 & 2049 & 12,141 \\
2 & F/M & 150 & 2092 & 596 & 350 & 1604 & 646 \\
3 & F/B & 60 & 99 & 183 & 171 & 294 & 57 \\
4 & F/VB & 36 & 0 & 92 & 108 & 80 & 12 \\
& Totally: & 2590 & 34,634 & 2995 & 1575 & 4027 & 12,856 \\
\hline 1 & LH/S & 5055 & 18,928 & 484 & 389 & 277 & 7111 \\
2 & LH/L & 21,244 & 173,792 & 7186 & 1476 & 13,246 & 114,706 \\
3 & LH/M & 549 & 2307 & 489 & 366 & 60 & 1026 \\
4 & LH/B & 12 & 40 & 16 & 12 & 0 & 24 \\
5 & LH/C & 0 & 0 & 0 & 0 & 0 & 0 \\
& Totally: & 26,860 & 195,067 & 8175 & 2243 & 13,583 & 122,867 \\
\hline
\end{tabular}

Source: own elaboration. 
Table A10. Risk indexes for particular categories of infrastructural objects in $2019\left(R 2019_{(F / L H) i, j}\right)$.

\begin{tabular}{cccccccc}
\hline \multirow{2}{*}{$C_{i}$} & Class of Consequence (i) & \multicolumn{7}{c}{ Category of Infrastructural Objects $(\boldsymbol{j})$} \\
\cline { 3 - 8 } & & $\mathbf{O 1}$ & $\mathbf{O 2}$ & $\mathbf{O 3}$ & $\mathbf{O 4}$ & $\mathbf{O 5}$ & O6 \\
\hline 1 & F/S & 2240 & 30,997 & 2023 & 827 & 1947 & 12,847 \\
2 & F/M & 146 & 1928 & 620 & 348 & 1408 & 800 \\
3 & F/B & 36 & 96 & 168 & 120 & 300 & 78 \\
4 & F/VB & 20 & 4 & 104 & 48 & 96 & 12 \\
& Totally: & 2442 & 33,025 & 2915 & 1343 & 3751 & 13,737 \\
\hline 1 & LH/S & 6601 & 20,670 & 462 & 265 & 273 & 7800 \\
2 & LH/L & 21,678 & 150,576 & 5448 & 1426 & 7262 & 133,352 \\
3 & LH/M & 903 & 2808 & 555 & 477 & 93 & 1383 \\
4 & LH/B & 24 & 60 & 12 & 4 & 4 & 104 \\
5 & LH/C & 0 & 0 & 0 & 0 & 0 & 0 \\
& Totally: & 29,206 & 174,114 & 6477 & 2172 & 7632 & 142,639 \\
\hline
\end{tabular}

\section{References}

1. Resolution adopted by the General Assembly on 25 September 2015. In Sustainable Development Goals; Wiley: Hoboken, NJ, USA, 2019; pp. 333-374.

2. Klimek, P.; Varga, J.; Jovanovic, A.S.; Szekely, Z. Quantitative resilience assessment in emergency response reveals how organizations trade efficiency for redundancy. Saf. Sci. 2019, 113, 404-414. [CrossRef]

3. Linkov, I.; Eisenberg, D.A.; Bates, M.E.; Chang, D.; Convertino, M.; Allen, J.H.; Flynn, S.E.; Seager, T.P. Measurable Resilience for Actionable Policy. Environ. Sci. Technol. 2013, 47, 10108-10110. [CrossRef]

4. Jovanovic, A.S.; Schmid, N.; Klimek, P.; Choudhary, A. Use of indicators for assessing resilience of Smart Critical Infrastructures. In IRGC Resource Guide on Resilience; Florin, M.V., Linkov, I., Eds.; EPFL International Risk Governance Center: Lausanne, Switzerland, 2016.

5. Zoomers, A.; Van Noorloos, F.; Otsuki, K.; Steel, G.; Van Westen, G. The Rush for Land in an Urbanizing World: From Land Grabbing Toward Developing Safe, Resilient, and Sustainable Cities and Landscapes. World Dev. 2017, 92, 242-252. [CrossRef]

6. Nan, C.; Sansavini, G. A quantitative method for assessing resilience of interdependent infrastructures. Reliab. Eng. Syst. Saf. 2017, 157, 35-53. [CrossRef]

7. Bertocchi, G.; Carrozzi, L.; Bologna, S.; Cavallini, S. Guidelines for Critical Infrastructure Resilience Evaluation; Technical report; The Italian Association of Critical Infrastructures' Experts: Rome, Italy, 2016; Available online: http://www.infrastrutturecritiche.it/new/media-files/2016/04/Guidelines_Critical_Infrastructures_ Resilience_Evaluation.pdf (accessed on 2 March 2020).

8. Gromek, P. Study on communication tools in terms of rescue needs in Poland. Int. J. Manag. Appl. Sci. 2017, 11, 66-71.

9. Son, C.; Sasangohar, F.; Neville, T.; Peres, S.C.; Moon, J. Investigating resilience in emergency management: An integrative review of literature. Appl. Ergon. 2020, 87, 103114. [CrossRef]

10. Cohen, O.; Goldberg, A.; Lahad, M.; Aharonson-Daniel, L. Building resilience: The relationship between information provided by municipal authorities during emergency situations and community resilience. Technol. Forecast. Soc. Chang. 2017, 121, 119-125. [CrossRef]

11. Chuang, S.; Ou, J.-C.; Ma, H.-P. Measurement of resilience potentials in emergency departments: Applications of a tailored resilience assessment grid. Saf. Sci. 2020, 121, 385-393. [CrossRef]

12. Tepes, A.; Neumann, M.B. Multiple perspectives of resilience: A holistic approach to resilience assessment using cognitive maps in practitioner engagement. Water Res. 2020, 178, 115780. [CrossRef]

13. Gasser, P.; Suter, J.; Cinelli, M.; Spada, M.; Burgherr, P.; Hirschberg, S.; Kadzinski, M.; Stojadinowic, B. Comprehensive resilience assessment of electricity supply security for 140 countries. Ecol. Indic. 2020, 110, 105731. [CrossRef]

14. Kurth, M.; Keenan, J.M.; Sasani, M.; Linkov, I. Defining resilience for the US building industry. Build. Res. Innov. 2019, 47, 480-492. [CrossRef] 
15. Rajkovich, N.B.; Okour, Y. Climate Change Resilience Strategies for the Building Sector: Examining Existing Domains of Resilience Utilized by Design Professionals. Sustainability 2019, 11, 2888. [CrossRef]

16. Wolanin, J. Common Societal Security Culture in the Baltic Sea Region: Basics and the Way Forward; Council of the Baltic Sea States (CBSS) Secretariat: Stockholm, Sweden, 2017.

17. Simak, L.; Holla, K.; Ristvej, J. Crisis Management in Public Administration. Crisis Management I. Theory of Crisis Management; University of Zilina Publishing House: Zilina, Slovak Republik, 2013.

18. Krasuski, A.; Kreński, K.; Łazowy, S. A Method for Estimating the Efficiency of Commanding in the State Fire Service of Poland. Fire Technol. 2012, 48, 795-805. [CrossRef]

19. Artachali, M.; Ghafory-Ashtiany, M.; Amini-Hosseini, K.; Arian-Moghaddam, S. Toward quantification of seismic resilience in Iran: Developing an integrated indicator system. Int. J. Disaster Risk Reduct. 2019, 39, 101231. [CrossRef]

20. Bibri, S.E.; Krogstie, J. Smart sustainable cities of the future: An extensive interdisciplinary literature review. Sustain. Cities Soc. 2017, 31, 183-212. [CrossRef]

21. Galaitsi, S.; Trump, B.D.; Keisler, J.M.; Linkov, I. The Need to Reconcile Concepts that Characterize Systems Withstanding Threats. Available online: https://arxiv.org/abs/1912.10457 (accessed on 2 March 2020).

22. Collier, Z.; Wang, D.; Vogel, J.T.; Tatham, E.K.; Linkov, I. Sustainable roofing technology under multiple constraints: A decision analytic approach. Environ. Syst. Decis. 2013, 33, 261-271. [CrossRef]

23. Burkeley, H.; Betsill, M. Rethinking sustainable cities: Multilevel governance and the urban politics of climate change. Environ. Politics 2005, 14, 42-63. [CrossRef]

24. Huovila, A.; Bosch, P.; Airaksinen, M. Comparative analysis of standardized indicators for Smart sustainable cities: What indicators and standards to use and when? Cities 2019, 89, 141-153. [CrossRef]

25. Duy, P.N.; Chapman, L.; Tight, M. Resilient transport systems to reduce urban vulnerability to floods in emerging-coastal cities: A case study of Ho Chi Minh City, Vietnam. Travel Behav. Soc. 2019, 15, 28-43. [CrossRef]

26. Stumpp, E.M. New in town? On resilience and "Resilient Cities". Cities 2013, 32, 164-166. [CrossRef]

27. Sharifi, A. Resilient urban forms: A review of literature on streets and street networks. Build. Environ. 2019, 147, 171-187. [CrossRef]

28. Spaans, M.; Waterhout, B. Building up resilience in cities worldwide-Rotterdam as participant in the 100 Resilient Cities Programme. Cities 2017, 61, 109-116. [CrossRef]

29. Hernantes, J.; Maraña, P.; Gimenez, R.; Sarriegi, J.M.; Labaka, L. Towards resilient cities: A maturity model for operationalizing resilience. Cities 2019, 84, 96-103. [CrossRef]

30. Bec, A.; Moyle, B.; Moyle, C. Resilient and Sustainable Communities. Sustainability 2018, 10, 4810. [CrossRef]

31. McEvoy, B. Climate Resilient Urban Development. Sustainability 2019, 11, 724. [CrossRef]

32. Lafortezza, R.; Chen, J.; Bosch, C.K.V.D.; Randrup, T.B. Nature-based Solutions for Resilient Landscapes and Cities. Environ. Res. 2018, 165, 431-441. [CrossRef]

33. Samah, N. Resilient Health Infrastructure: Strengthening hospitals' capacity to respond effectively during disasters and crises. Procedia Eng. 2018, 212, 262-269. [CrossRef]

34. Lomba-Fernández, C.; Hernantes, J.; Labaka, L. Guide for Climate-Resilient Cities: An Urban Critical Infrastructures Approach. Sustainability 2019, 11, 4727. [CrossRef]

35. Yang, Y.; Ng, S.T.; Xu, F.J.; Skitmore, M. Towards sustainable and resilient high density cities through better integration of infrastructure networks. Sustain. Cities Soc. 2018, 42, 407-422. [CrossRef]

36. Gimenez, R.; Labaka, L.; Hernantes, J. A maturity model for the involvement of stakeholders in the city resilience building process. Technol. Forecast. Soc. Chang. 2017, 121, 7-16. [CrossRef]

37. Linkov, I.; Bridges, T.; Creutzig, F. Changing the resilience paradigm. Nat. Clim. Chang. 2014, 4, 407-409. [CrossRef]

38. National Research Council. Disaster Resilience: A National Imperative; The National Academies Press: Washington, DC, USA, 2012.

39. Marchese, D.; Reynolds, E.; Bates, M.E.; Morgan, H.; Clark, S.S.; Linkov, I. Resilience and sustainability: Similarities and differences in environmental management applications. Sci. Total Environ. 2018, 613, 1275-1283. [CrossRef] [PubMed]

40. Nateghi, R. Multi-Dimentional Infrastructure Resilience Modeling: An Application to Hurricane-Prone Electric Power Distribution Systems. IEEE Access 2018, 6, 13478-13489. [CrossRef] 
41. Hwang, K.; Schuetze, T.; Amoruso, F.M. Flood Resilient and Sustainable Urban Regeneration Using the Example of an Industrial Compound Conversion in Seoul, South Korea. Sustainability 2020, 12, 918. [CrossRef]

42. Lawson, E.; Farmani, R.; Woodley, E.; Butler, D. A Resilient and Sustainable Water Sector: Barriers to the Operationalisation of Resilience. Sustainability 2020, 12, 1797. [CrossRef]

43. Lu, Z.; Zhou, Y.; Yang, T.; Papalou, A. Special Issue: Resilience and Sustainability of Civil Infrastructures under Extreme Loads. Sustainability 2019, 11, 3292. [CrossRef]

44. Kloosterman, R.A.; Veeneman, W.; Hoek, J.P.V.D. Sustainable Societal Infrastructures: A Resilient Approach to Prevent Conflicting Claims of Drinking Water and Other Infrastructures. Sustainability 2020, 12, 785. [CrossRef]

45. Desouza, K.C.; Flanery, T.H. Designing, planning, and managing resilient cities: A conceptual framework. Cities 2013, 35, 89-99. [CrossRef]

46. Bibri, S.E. The Shaping of Ambient Intelligence and the Internet of Things: Historico-Epistemic, Socio-Cultural, Politico-Institutional and Eco-Environmental Dimensions; Springer-Verlag: Berlin, Germany, 2015.

47. Ongkowijoyo, C.; Doloi, H. Risk-based Resilience Assessment Model Focusing on Urban Infrastructure System Restoration. Procedia Eng. 2018, 212, 1115-1122. [CrossRef]

48. Rehak, D.; Šenovský, P.; Hromada, M.; Lovecek, T. Complex approach to assessing resilience of critical infrastructure elements. Int. J. Crit. Infrastruct. Prot. 2019, 25, 125-138. [CrossRef]

49. Ritchey, T. Morphological Gap-Analysis. Acta Morphol. Gen. 2013, 2, 1-14.

50. Ritchey, T. General morphological analysis as a basic scientific modelling method. Technol. Forecast. Soc. Chang. 2018, 126, 81-91. [CrossRef]

51. Moser, S.C.; Ekstrom, J.A. A framework to diagnose barriers to climate change adaptation. Proc. Natl. Acad. Sci. USA 2010, 107, 22026-22031.

52. Linkov, I.; Fox-Lent, C.; Read, L.; Allen, C.R.; Arnott, J.C.; Bellini, E.; Coaffee, J.; Florin, M.-V.; Hatfield, K.; Hyde, I.; et al. Tiered Approach to Resilience Assessment. Risk Anal. 2018, 38, 1772-1780. [CrossRef] [PubMed]

53. Sharifi, A. A critical review of selected tools for assessing community resilience. Ecol. Indic. 2016, 69, 629-647. [CrossRef]

54. Cutter, S.L. The landscape of disaster resilience indicators in the USA. Nat. Hazards 2015, 80, 741-758. [CrossRef]

55. Mitroliou, E.; Bizzotto, M. Resilient Cities: Congress Report; ICLEI: Bonn, Germany, 2012.

56. Wagner, I.; Breil, P. The role of ecohydrology in creating more resilient cities. Ecohydrol. Hydrobiol. 2013, 13, 113-134. [CrossRef]

57. City Resilience Index. City Resilience Framework. The Rockefeller Foundation. Available online: https: //assets.rockefellerfoundation.org/app/uploads/20150530121930/City-Resilience-Framework1.pdf (accessed on 2 March 2020).

58. Zhong, M.; Lin, K.; Tang, G.; Zhang, Q.; Hong, Y.; Chen, X. A Framework to Evaluate Community Resilience to Urban Floods: A Case Study in Three Communities. Sustainability 2020, 12, 1521. [CrossRef]

59. Wang, Y.; Shen, J.; Xiang, W.-N.; Wang, J. Identifying characteristics of resilient urban communities through a case study method. J. Urban Manag. 2018, 7, 141-151. [CrossRef]

60. Poku-Boansi, M.; Cobbinah, P. Are we planning for resilient cities in Ghana? An analysis of policy and planners' perspectives. Cities 2018, 72, 252-260. [CrossRef]

61. Hossain, N.U.I.; Jaradat, R.; Hosseini, S.; Marufuzzaman, M.; Buchanan, R.K. A framework for modeling and assessing system resilience using a Bayesian network: A case study of an interdependent electrical infrastructure system. Int. J. Crit. Infrastruct. Prot. 2019, 25, 62-83. [CrossRef]

62. ISO 22301. Societal Security-Business Continuity Management Systems-Requirements; International Organization for Standardization: Geneva, Switzerland, 2012.

63. Kameshwar, S.; Cox, D.T.; Barbosa, A.R.; Farokhnia, K.; Park, H.; Alam, M.S.; Van De Lindt, J.W. Probabilistic decision-support framework for community resilience: Incorporating multi-hazards, infrastructure interdependencies, and resilience goals in a Bayesian network. Reliab. Eng. Syst. Saf. 2019, 191, 106568. [CrossRef]

64. Wang, W.; Yang, S.; Hu, F.; Stanley, H.E.; He, S.; Shi, M. An approach for cascading effects within critical infrastructure systems. Phys. A Stat. Mech. Appl. 2018, 510, 164-177. [CrossRef] 
65. Shakou, L.M.; Wybo, J.-L.; Reniers, G.; Boustras, G. Developing an innovative framework for enhancing the resilience of critical infrastructure to climate change. Saf. Sci. 2019, 118, 364-378. [CrossRef]

66. Rehak, D. Assessing and strengthening organisational resilience in a critical infrastructure system: Case study of the Slovak Republic. Saf. Sci. 2020, 123, 104573. [CrossRef]

67. Fox-Lent, C.; Bates, M.E.; Linkov, I. A matrix approach to community resilience assessment: An illustrative case at Rockaway Peninsula. Environ. Syst. Decis. 2015, 35, 209-218. [CrossRef]

68. Huck, A.; Monstadt, J.; Driessen, P. Building urban and infrastructure resilience through connectivity: An institutional perspective on disaster risk management in Christchurch, New Zealand. Cities 2020, 98, 102573. [CrossRef]

69. Dewulf, A.; Meijerink, S.; Runhaar, H. Editorial: The governance of adaptation to climate change as a multi-level, multi-sector and multi-actor challenge: A European comparative perspective. J. Water Clim. Chang. 2015, 6, 1-8. [CrossRef]

70. Vedeld, T.; Coly, A.; Ndour, N.M.; Hellevik, S. Climate adaptation at what scale? Multi-level governance, resilience, and coproduction in Saint Louis, Senegal. Nat. Hazards 2015, 82, 173-199. [CrossRef]

71. Information about Emergency Interventions of SFRS Entities. The Main Headquarters of SFS. Available online: https://www.straz.gov.pl/panstwowa_straz_pozarna/interwencje_psp (accessed on 2 March 2020).

72. Krasuski, A. Multisimulation: Stochastic Simulations for the Assessment of Building Fire Safety; The Main School of Fire Service Publishing House: Warsaw, Poland, 2019.

73. Ministry of Interior and Public Administration of the Republic of Poland. Executory Law on Particular Organization of State Firefighting Rescue System; The Sejm: Warsaw, Poland, 2017.

74. The Main Headquarters of The State Fire Service. Guidelines for Incidents' Records in Decision Support System of SFS; The State Fire Service: Warsaw, Poland, 2019.

75. Koziol, J.; Gromek, P. Creating Safety in Transport - Traffic Risk Approach. Procedia Eng. 2017, 192, 457-462. [CrossRef]

76. Bostick, T.; Connelly, E.; Lambert, J.; Linkov, I. Resilience science, policy and investment for civil infrastructure. Reliab. Eng. Syst. Saf. 2018, 175, 19-23. [CrossRef]

77. Goel, A.; Ganesh, L.; Kaur, A. Sustainability integration in the management of construction projects: A morphological analysis of over two decades' research literature. J. Clean. Prod. 2019, 236, 117676. [CrossRef]

78. Lantada, N.; Carreño, M.L.; Jaramillo, N. Disaster risk reduction: A decision-making support tool based on the morphological analysis. Int. J. Disaster Risk Reduct. 2020, 42, 101342. [CrossRef]

79. Zhou, J.; Reniers, G. Petri-net based evaluation of emergency response actions for preventing domino effects triggered by fire. J. Loss Prev. Process. Ind. 2018, 51, 94-101. [CrossRef]

80. Gromek, P.; Wrobel, R. Crucial Objects Protection. Societal Security Perspective; The Main School of Fire Service Publishing House: Warsaw, Poland, 2017.

81. Gromek, P.; Wrobel, R. Crucial Objects Protection. Crisis Management, Risk Management and Continuity Management; The Main School of Fire Service Publishing House: Warsaw, Poland, 2018.

(C) 2020 by the authors. Licensee MDPI, Basel, Switzerland. This article is an open access article distributed under the terms and conditions of the Creative Commons Attribution (CC BY) license (http://creativecommons.org/licenses/by/4.0/). 